\title{
Characterization of organic nitrate constituents of secondary organic aerosol (SOA) from nitrate-radical-initiated oxidation of limonene using high-resolution chemical ionization mass spectrometry
}

\author{
Cameron Faxon, Julia Hammes, Michael Le Breton, Ravi Kant Pathak, and Mattias Hallquist \\ Department of Chemistry and Molecular biology, University of Gothenburg, Göteborg, 41258, Sweden
}

Correspondence: Mattias Hallquist (hallq@ chem.gu.se)

Received: 26 June 2017 - Discussion started: 27 June 2017

Revised: 12 January 2018 - Accepted: 29 January 2018 - Published: 20 April 2018

\begin{abstract}
The gas-phase nitrate radical $\left(\mathrm{NO}_{3}^{*}\right)$ initiated oxidation of limonene can produce organic nitrate species with varying physical properties. Low-volatility products can contribute to secondary organic aerosol (SOA) formation and organic nitrates may serve as a $\mathrm{NO}_{x}$ reservoir, which could be especially important in regions with high biogenic emissions. This work presents the measurement results from flow reactor studies on the reaction of $\mathrm{NO}_{3}^{*}$ with limonene using a High-Resolution Time-of-Flight Chemical Ionization Mass Spectrometer (HR-ToF-CIMS) combined with a Filter Inlet for Gases and AEROsols (FIGAERO). Major condensed-phase species were compared to those in the Master Chemical Mechanism (MCM) limonene mechanism, and many non-listed species were identified. The volatility properties of the most prevalent organic nitrates in the produced SOA were determined. Analysis of multiple experiments resulted in the identification of several dominant species (including $\mathrm{C}_{10} \mathrm{H}_{15} \mathrm{NO}_{6}, \mathrm{C}_{10} \mathrm{H}_{17} \mathrm{NO}_{6}, \mathrm{C}_{8} \mathrm{H}_{11} \mathrm{NO}_{6}, \mathrm{C}_{10} \mathrm{H}_{17} \mathrm{NO}_{7}$, and $\mathrm{C}_{9} \mathrm{H}_{13} \mathrm{NO}_{7}$ ) that occurred in the SOA under all conditions considered. Additionally, the formation of dimers was consistently observed and these species resided almost completely in the particle phase. The identities of these species are discussed, and formation mechanisms are proposed. Cluster analysis of the desorption temperatures corresponding to the analyzed particle-phase species yielded at least five distinct groupings based on a combination of molecular weight and desorption profile. Overall, the results indicate that the oxidation of limonene by $\mathrm{NO}_{3}^{*}$ produces a complex mixture of highly oxygenated monomer and dimer products that contribute to SOA formation.
\end{abstract}

\section{Introduction}

Oxidation of gas-phase organic species contributes significantly to particle formation and growth (Hallquist et al., 2009; Smith et al., 2008; Wehner et al., 2005), and thus a thorough understanding of secondary organic aerosol (SOA) formation mechanisms is important for the accurate estimation of its impact on the climate system (Kanakidou et al., 2005).

Secondary organic aerosols form primarily via the photooxidation of volatile organic compounds (VOCs), yielding less volatile products, which can then partition into the condensed phase (Hallquist et al., 2009; Kroll and Seinfeld, 2008), especially when preexisting aerosols (e.g., inorganic seed particles) are present (Kroll et al., 2007). The products resulting from atmospheric oxidation may be classified as low-volatility, semi-volatile, and intermediate-volatility OCs, i.e., LVOCs, SVOCs, and IVOCs, respectively (Donahue et al., 2012; Jimenez et al., 2006; Murphy et al., 2014). In addition, extremely low-volatility OCs (i.e., ELVOCs) contribute significantly to aerosol formation and early growth (Ehn et al., 2014; Jokinen et al., 2015). The oxidation of VOCs by the primary atmospheric oxidants, $\mathrm{O}_{3}$ and ${ }^{\circ} \mathrm{OH}$, has been extensively investigated (Cao and Jang, 2008; Hallquist et al., 2009; Kanakidou et al., 2005; Kroll and Seinfeld, 2008). Although less studied than the photooxidation of VOCs, the reaction of VOCs with the nitrate radical $\left(\mathrm{NO}_{3}^{*}\right)$ and the resulting formation of organic nitrates are also important, especially for nocturnal chemistry (Roberts, 1990; Brown and Stutz, 2012; Perring et al., 2013; Kiendler-Scharr 
et al., 2016; $\mathrm{Ng}$ et al., 2017). Significant concentrations of these nitrates have been detected in the gas and condensed phases in both field and laboratory studies (Ayres et al., 2015; Beaver et al., 2012; Boyd et al., 2017; Bruns et al., 2010; Day et al., 2010; Fry et al., 2014; Lee et al., 2016; Nah et al., 2016; Paulot et al., 2009; Rindelaub et al., 2014, 2015; Rollins et al., 2012, 2013; Xu et al., 2016; Kiendler-Scharr et al., 2016).

Organic nitrates $\left(\mathrm{RONO}_{2}\right)$ and organic peroxy nitrates $\left(\mathrm{RO}_{2} \mathrm{NO}_{2}\right)$, such as peroxy acetyl nitrate (PAN), may also form in the atmosphere (Roberts, 1990; Singh and Hanst, 1981; Temple and Taylor, 1983). $\mathrm{RO}_{2} \mathrm{NO}_{2}$ may form via the reaction of organic peroxy nitrates $\left(\mathrm{RO}_{2}^{*}\right)$ with $\mathrm{NO}_{2}$, while $\mathrm{RONO}_{2}$ may form directly through either the reaction of $\mathrm{RO}_{2}^{*}$ with $\mathrm{NO}$ or the reaction of unsaturated VOCs with $\mathrm{NO}_{3}^{*}$.

Secondary organic aerosol-precursor VOCs arise mainly from the emission and reaction of biogenic VOCs (BVOCs) (Hallquist et al., 2009), with up to $90 \%$ of the global VOC budget originating from biogenic sources (Glasius and Goldstein, 2016; Guenther et al., 1995). Isoprene, the main constituent of global BVOC terrestrial emissions $\left(600 \mathrm{Tg} \mathrm{yr}^{-1}\right)$ (Guenther et al., 2006), is highly reactive with ${ }^{\circ} \mathrm{OH}, \mathrm{O}_{3}$, and $\mathrm{NO}_{3}^{*}$ (Atkinson et al., 1995; Hallquist et al., 2009). However, monoterpenes typically have higher SOA yields than isoprene (Carlton et al., 2009; Presto et al., 2005b) and regarding atmospheric emissions, $\alpha$-pinene, $\beta$-pinene, and limonene constitute the main monoterpenes emitted into the atmosphere (Guenther et al., 2012). In addition to its high emission rates, limonene is especially interesting as a model BVOC, due to its relatively high reaction rates (Ziemann and Atkinson, 2012) and occurrence in indoor environments, owing to emission sources, such as air fresheners and other household products (Wainman et al., 2000).

The reactions and mechanisms of $\alpha$-pinene and $\beta$-pinene oxidation have been more thoroughly studied (Bonn and Moorgat, 2002; Presto et al., 2005a, b; Fry et al., 2009; Perraud et al., 2010) than those associated with limonene. Several studies have focused on the ozonolysis of limonene and SOA formation from limonene (Leungsakul et al., 2005; Jonsson et al., 2006, 2008a; Zhang et al., 2006; Baptista et al., 2011; Sun et al., 2011; Pathak et al., 2012; Jiang et al., 2013; Youssefi and Waring, 2014;). $\mathrm{NO}_{3}^{\circ}$ oxidation of limonene and the resulting organic nitrates that may contribute to SOA formation have, however, rarely been investigated ( Hallquist et al., 1999; Spittler et al., 2006; Fry et al., 2011, 2014; Boyd et al., 2017). In relation to the reaction with $\mathrm{NO}_{3}^{\cdot}$, major nonnitrate products of limonene (including endolim) have been identified, but significant SOA formation was preceded by the occurrence of multiple unidentified nitrates (Hallquist et al., 1999; Spittler et al., 2006). Moreover, although mechanistic models and molecular identities of these products have been proposed, direct measurement and identification thereof have yet to be reported. Further elucidation of the mechanisms governing the reactions of limonene and $\mathrm{NO}_{3}^{*}$ and the resultant products generated is warranted, since organic nitrates from BVOCs (including limonene) have been consis- tently observed in field studies (Perring et al., 2009; Ayres et al., 2015; Beaver et al., 2012; Lee et al., 2016, 2014b;).

Additionally, the contribution of low-volatility products to the SOA mass may increase with the formation of dimers from aerosol components generated by VOC oxidation. $\mathrm{Nu}-$ merous dimers or oligomers have been found in SOA generated by monoterpene species (e.g., Emanuelsson et al., 2013; Kourtchev et al., 2014, 2016; Kristensen et al., 2016; Müller et al., 2008; Tolocka et al., 2004). However, the speciation of observed dimers and oligomers from organic nitrates, especially with respect to detailed formation mechanisms, has rarely been reported.

Here we report the chemical composition of low-volatility gas and aerosol-phase species, formed from mixtures of $\mathrm{N}_{2} \mathrm{O}_{5}$ and limonene, as measured by a High Resolution Time-of-Flight Chemical Ionization Mass Spectrometer (HR-ToF-CIMS) coupled to a Filter Inlet for Gases and AEROsols (FIGAERO) (Lopez-Hilfiker et al., 2014). The objectives of this work were three-fold, namely, to (i) determine the molecular formulae of major nitrate species produced from the reaction of limonene with $\mathrm{NO}_{3}^{*}$, which could contribute significantly to SOA formation and growth; (ii) compare the distribution of measured products to that of the expected products (based on the Master Chemical Mechanism (MCM)) to identify any discrepancies in the mechanistic understanding of nitrate formation from limonene; and (iii) categorize, via cluster analysis, the thermodynamic desorption data measured for selected condensed-phase species.

\section{Methods}

\subsection{Experimental setup}

Experiments were performed in the Gothenburg Flow Reactor for Oxidation Studies at low Temperatures (G-FROST) at the University of Gothenburg. In previous studies, this facility was used for studying the impact of relative humidity, $\mathrm{OH}$ scavengers, and temperature on SOA formation via monoterpene ozonolysis (Emanuelsson et al., 2013; Jonsson et al., 2008a, b), its volatility properties (Pathak et al., 2012), and dimer formation during the ozonolysis of $\alpha$-pinene (Kristensen et al., 2016). The inflow of zero air and the reagents is fixed at a total flow of $1.6 \mathrm{~L}$ per min $(\mathrm{LPM})$. The experiments are all run at low relative humidity $(\mathrm{RH})(\leq 1 \%)$ and a constant temperature of $20^{\circ} \mathrm{C}$. To catch only the center portion of the laminar flow and avoid unnecessary interference from wall effects, samples are taken through a cone at the end of the reactor at $0.95 \mathrm{LPM}$. The average residence time of the sampled portion of the mixture is $240 \mathrm{~s}$. Due to the flow restrictions, a makeup flow of zero air is added to the sample, immediately after the outlet, prior to being sampled by the instruments. The amount of dilution flow necessary is constrained by the flow required by the HR-ToF-CIMS. Figure 1 shows a diagram of the experimental setup. 


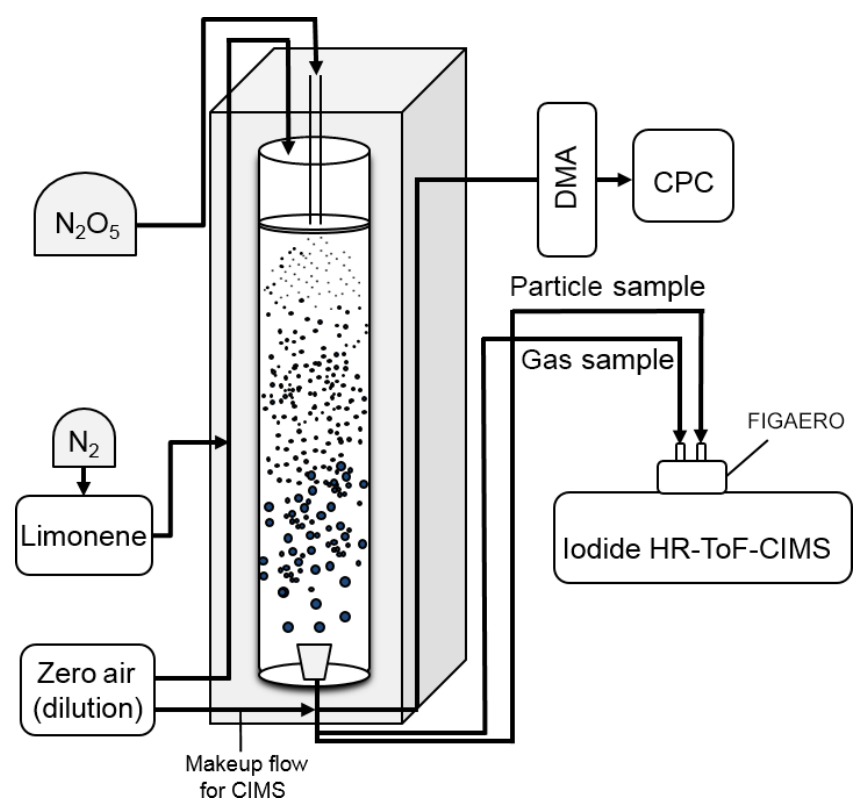

Figure 1. Diagram of experimental setup of G-FROST during experiments.

Gas- and particle-phase products were measured using a High-Resolution Time-of-Flight Chemical Ionization Mass Spectrometer (HR-ToF-CIMS) coupled to a Filter Inlet for Gases and AEROsols (FIGAERO) (Lopez-Hilfiker et al., 2014). The HR-ToF-CIMS can be operated in either negative- or positive-ionization modes, using various reagent ion sources. CIMS measurement techniques have previously been employed for the measurement of organic nitrate products of monoterpenes (Beaver et al., 2012; Paulot et al., 2009) using multiple reagent ions (Lee et al., 2014a). In this work, the HR-ToF-CIMS was operated using a negative iodide $\left(\mathrm{I}^{-}\right)$ ion as the reagent in all experiments. Dry ultra-high-purity (UHP) $\mathrm{N}_{2}$ was passed over a permeation tube containing liquid $\mathrm{CH}_{3} \mathrm{I}$ (Alfa Aesar, $99 \%$ ), and $\mathrm{I}_{2}\left(\mathrm{H}_{2} \mathrm{O}\right)_{n}^{-}$ions were generated by directing the flow over a ${ }^{210}$ Po radioactive source. Reaction products (e.g., specie $X$ ) were identified by their corresponding cluster ions, $\mathrm{XI}^{-}$, thereby allowing the collection of whole-molecule data. The reagent and sample flowed into the ion-molecule reaction (IMR) chamber of the instrument at a nominal individual rate of 2 LPM. The IMR was temperature-controlled at $40^{\circ} \mathrm{C}$ and operated at a nominal pressure of 200 mbar. With $\mathrm{I}^{-}$ionization, the sensitivity of a detected species (i.e., $\mathrm{hz} \mathrm{ppt}^{-1}$ ) can vary significantly with relative humidity (Lee et al., 2014a). However, the experiments were all performed at low RH $(\leq 1 \%)$ and, hence, the same sensitivity was realized for all the conditions considered.

The FIGAERO was used during the experiments, and particles were collected on a Zefluor ${ }^{\circledR}$ PTFE membrane filter. The aerosol sample line and gas sample line were composed of $12 \mathrm{~mm}$ copper tubing and $12 \mathrm{~mm}$ Teflon tubing, respectively. The inlet was operated in regular cycles $-1 \mathrm{~h}$ of gas-phase sampling and simultaneous particle collection, followed by a $1 \mathrm{~h}$ period where the filter was shifted into position over the IMR inlet and the collected SOA was desorbed. Desorption was facilitated by a 2 LPM flow of heated UHP $\mathrm{N}_{2}$ over the filter. The temperature of the $\mathrm{N}_{2}$ was increased from 20 to $200{ }^{\circ} \mathrm{C}$ in $50 \mathrm{~min}\left(3.5^{\circ} \mathrm{C} \mathrm{min}{ }^{-1}\right)$, and a subsequent $10 \mathrm{~min}$ temperature soak was performed to ensure complete removal of the remaining organic material that volatilizes at $200^{\circ} \mathrm{C}$. The measured species were distinguished based on their thermal properties via the resulting desorption time-series profiles, hereafter referred to as thermograms. Temperature gradients of $>3.5^{\circ} \mathrm{C} \mathrm{min}^{-1}$ have been used in previous studies, but, in this work, a lower gradient was used to enable optimum thermal separation (Lee et al., 2014a; Lopez-Hilfiker et al., 2014). The HR-ToF-CIMS was configured to measure singly charged ions with a massto-charge ratio $(\mathrm{m} / \mathrm{z}$ or Th) of 7-720. Particles were contemporaneously sampled directly at the outlet of the flow reactor, through a $1 / 4^{\prime \prime}$ stainless steel $1 \mathrm{~m}$ sample line, by a Scanning Mobility Particle Sizer (SMPS). The SMPS measured the number-size distribution used for estimating the mass concentrations, based on the assumption of spherical particles with a density of $1.4 \mathrm{~g} \mathrm{~cm}^{-3}$ (Hallquist et al., 2009). In all cases, SOA was generated via nucleation and growth rather than by using seed particles.

$\mathrm{N}_{2} \mathrm{O}_{5}$ was synthesized by reacting $\geq 20 \mathrm{ppm} \mathrm{O}_{3}$ with pure $\mathrm{NO}_{2}$ (98\%, AGA Gas) in a glass vessel and then passing the flow through a cold trap maintained at $-78.5^{\circ} \mathrm{C}$ using dry ice. Even if neither $\mathrm{HNO}_{3}$ nor $\mathrm{NO}_{2}$ was measured it is known from previous work that this method typically provides a source with impurities less than a few percent. It is well known that the resulting white solid would show signs of yellowing, due to nitric or nitrous acid contamination, if exposed to moisture (e.g., ambient lab air), so handling of the $\mathrm{N}_{2} \mathrm{O}_{5}$ was done accordingly. The solid $\mathrm{N}_{2} \mathrm{O}_{5}$ was transferred to a diffusion vial fitted with a capillary tube (inner diameter: $2 \mathrm{~mm}$ ). The $\mathrm{N}_{2} \mathrm{O}_{5}$ diffusion source was held at a constant temperature $\left(-23^{\circ} \mathrm{C}\right)$, and the gravimetrically determined mass loss rate remained steady ( $r^{2}$ value: $\left.0.97-0.98\right)$ for several weeks. A similarly characterized d-limonene (Alfa Aesar, $97 \%$ ) diffusion source was held at temperatures ranging from 8.5 to $31.5^{\circ} \mathrm{C}$ and, using gas chromatography-mass spectrometry (GC-MS instrument; Finnigan/Tremetrics), diluted flow-reactor concentrations $(15,45,92$, and $150 \mathrm{ppb})$.

Experiments were performed over a range (1.0-113) of $\mathrm{N}_{2} \mathrm{O}_{5}$ / limonene ratios (see Table 1 for a summary of experimental conditions). At a ratio of around 1.0 one expects only the endocyclic double bond to be reacting with $\mathrm{NO}_{3}$ radicals, while at a higher ratio there is an increased possibility for secondary chemistry where products will be susceptible to a reaction with the $\mathrm{NO}_{3}$ radical. For each set of conditions in the flow reactor, sampling was performed over a period of 6$12 \mathrm{~h}$ to ensure stability of conditions (e.g., gas-phase signals, total SOA mass) and repeatability of the FIGAERO thermal 
Table 1. Table 1. Experimental conditions, concentrations, and ratios of initial reactants and the resulting SOA mass.

\begin{tabular}{lrrrr}
\hline No. & $\begin{array}{r}\mathrm{N}_{2} \mathrm{O}_{5} \\
(\mathrm{ppb})\end{array}$ & $\begin{array}{r}\text { Limonene } \\
(\mathrm{ppb})\end{array}$ & $\begin{array}{r}\mathrm{N}_{2} \mathrm{O}_{5} / \\
\text { limonene }\end{array}$ & $\begin{array}{r}\text { Average SOA } \\
\text { mass* }\end{array}$ \\
\hline 3 & 95 & 15 & 6.3 & $12 \pm 2$ \\
4 & 95 & 15 & 6.3 & $8 \pm 1$ \\
2 & 95 & 40 & 2.4 & $8 \pm 1$ \\
5 & 95 & 40 & 2.4 & $10 \pm 1$ \\
6 & 95 & 95 & 1 & $12 \pm 1$ \\
1 & 160 & 15 & 10.7 & $8 \pm 1$ \\
11 & 850 & 95 & 8.9 & $25 \pm 2$ \\
12 & 850 & 150 & 5.7 & $47 \pm 2$ \\
7 & 1700 & 15 & 113.3 & $7 \pm 1$ \\
8 & 1700 & 40 & 42.5 & $11 \pm 1$ \\
9 & 1700 & 95 & 17.9 & $43 \pm 2$ \\
10 & 1700 & 150 & 11.3 & $95 \pm 3$ \\
\hline
\end{tabular}

* Errors are given as standard deviation of the measured mean.

desorption cycles. An example of three sequential cases of desorption is shown in Fig. S2 in the Supplement.

\subsection{CIMS data analysis methods}

Data obtained from the HR-ToF-CIMS were analyzed using the Tofware (Tofwerk/Aerodyne) analysis software written in Igor Pro (WaveMetrics). High-resolution analysis allowed for ion identification with a resolution of $\sim 4000(\mathrm{~m} / \Delta \mathrm{m})$. Identified species were cross-checked with predicted species generated via the MCM v3.3.1 limonene mechanism (Saunders et al., 2003) and the corresponding theoretical product distribution was compared with the measured distribution for both the gas and particle phase. For several ions, product formulas in the MCM were used as the major parameter for ion identification at a given $m / z$. However, this identification scheme resulted in the misidentification of several ions. The identification of high-mass ions $(m / z>500)$ was complicated by the fact that the number of possible formulas increases rapidly with increasing mass and carbon number of the ions. Nevertheless, the high accuracy of fits $(\leq 5 \mathrm{ppm})$, where the identities of expected product ions were corroborated by the fits of expected isotopes, reduced uncertainties stemming from the mass calibration and provided reliable ion identifications. To further ensure the accuracy of the identities of high-mass ions, the fits of the identified ions were compared over all experiments.

The high-resolution ion data were further analyzed with Python 3.5.2 using the pandas (McKinney, 2010, 2011) and NumPy (Van Der Walt et al., 2011) packages, and peaks in the ion thermograms were identified using an implementation of the PeakUtils package (v1.0.3, https://pypi.python. org/pypi/PeakUtils). For each experiment, the temperature $\left(T_{\max }\right)$ corresponding to the peak signal of each ion observed during the desorption of SOA particles was identified. Fur- thermore, a secondary temperature $\left(T_{\max , 2}\right)$ was identified when double-peak behavior was observed.

\subsection{Cluster analysis methods}

Cluster analysis, performed via the K-Means algorithm (scikit-learn machine learning package; Pedregosa et al., 2011), was used to distinguish, based on their elemental composition and thermodynamic behavior $\left(T_{\max }\right)$, groups of ions observed during SOA desorption. This algorithm, utilizing a random seeding approach (Arthur and Vassilvitskii, 2007), was chosen due to the superior cluster separation realized after comparing several algorithms, including affinity propagation and mean shift clustering. The solution of the K-Means algorithm is obtained through the minimization of an inertia function (see Eq. 1) $\Phi$, which is equivalent to the sum of the mean squared distance between all samples and their corresponding cluster centroid, c (Arthur and Vassilvitskii, 2007; Raschka, 2015). Here, $x^{(i)}$ is the sample (e.g., carbon number, oxygen number, $\left.T_{\max }\right)$ in a set of $n$ samples, $c^{(j)}$ is the cluster center of cluster $j$ in a set of $k$ clusters, and $w^{(i, j)}$ is the weighting coefficient $\left(w^{(i, j)}=1\right.$ if $x^{(i)}$ is in cluster $j$, $w^{(i, j)}=0$ otherwise).

$\phi=\sum_{i=1}^{n} \sum_{j=1}^{k} w^{(i, j)}\left\|x^{(i)}-c^{(j)}\right\|^{2}$

The quality of the cluster separation was assessed through a silhouette score, $s(i)$ (Rousseeuw, 1987), which allows comparison of the intra-cluster and inter-cluster distances and, for a sample $i$, is determined from

$s(i)=\frac{b(i)-a(i)}{\max \{a(i), b(i)\}}$,

where $a(i)$ is the average distance, or dissimilarity, between point $i$ and each point within its own cluster and $b(i)$ is the average dissimilarity between point $i$ and all points within the nearest neighboring cluster. The value of $s(i)$ ranges from -1 to 1 and reflects the quality of the clustering with respect to the separation between members of each cluster. For example, a score of $\sim 1$ indicates that the point is relatively far away from the nearest neighboring cluster, while a score of 0 suggests that the cluster separation is roughly equivalent to that of cohesion clusters; that is, $a(i) \approx b(i)$. For all points within a clustered dataset, an average silhouette score can indicate the adequacy of the cluster separation for a given number of clusters.

Detected ions were clustered based on their molecular weight (MW), elemental numbers $\left(n_{\mathrm{c}}, n_{\mathrm{H}}, n_{\mathrm{O}}, n_{\mathrm{N}}\right)$, and $T_{\max }$ values. Compared with the other variables, MW and the carbon number exhibited the highest correlation with $T_{\max }$. Clustering the ions based on these three variables yielded the best separation with respect to mass and $T_{\max }$ of the ions. Input variables were scaled to values between 0 and 1 (based on their respective range of input values) to prevent any bias associated with the relative magnitude of each variable (e.g., $\mathrm{MW} \gg n_{\mathrm{C}}$ ). 


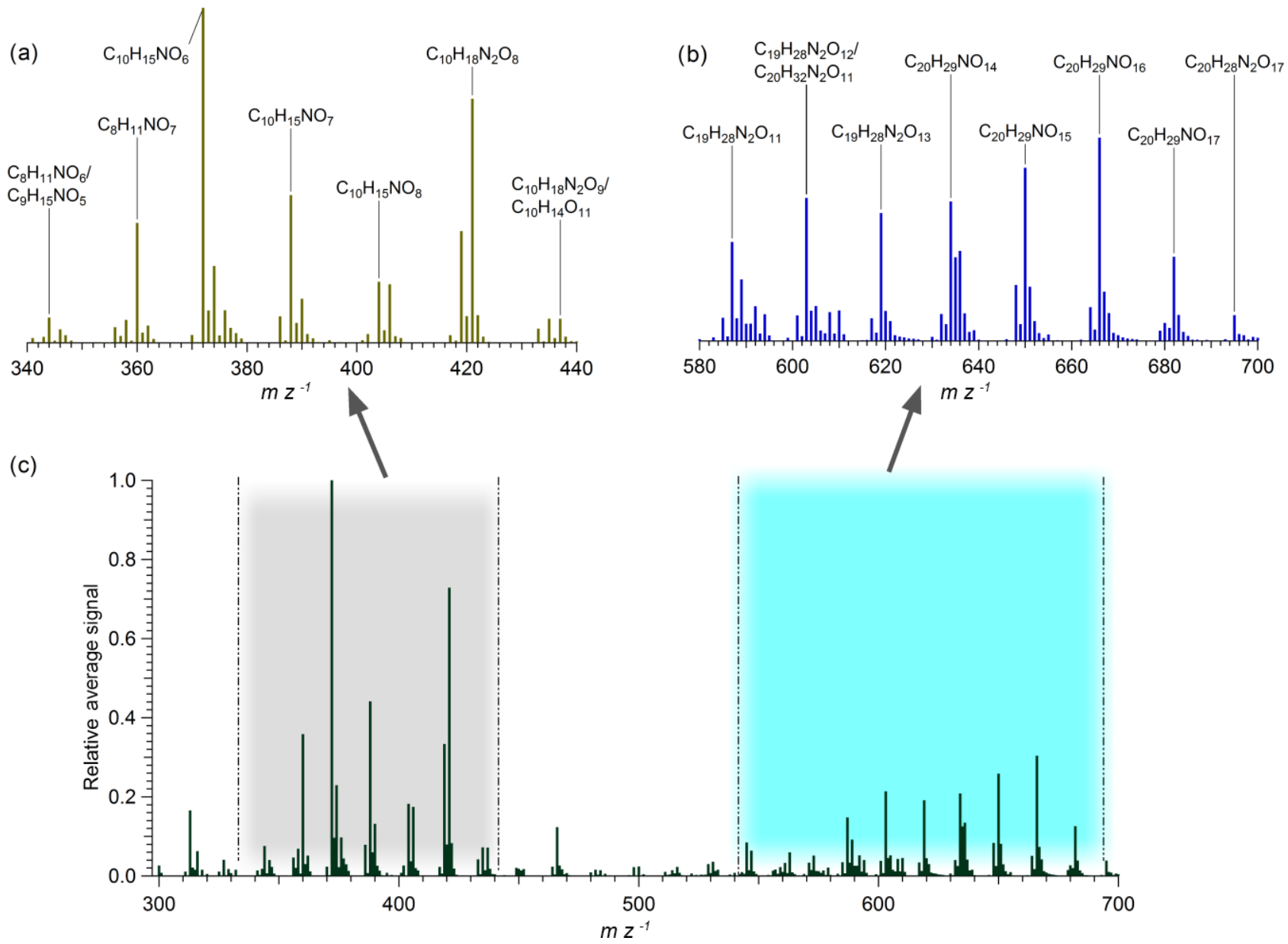

Figure 2. Representative average mass spectrum for the desorption of SOA collected during the experiments: identification of ions detected in the (a) monomer region $(\mathrm{m} / \mathrm{z}, 340-440)$ and (b) dimer region $(\mathrm{m} / \mathrm{z}$ 580-700). (c) Relative intensities and positions of the two regions detected in all aerosol samples. Data were obtained from four $1 \mathrm{~h}$ desorption cycles of $12 \mu \mathrm{m}^{-3}$ samples from a mixture with a $\mathrm{N}_{2} \mathrm{O}_{5} /$ limonene ratio of 2.4. The un-clustered (i.e., not clustered with $\mathrm{I}^{-}$) $\mathrm{m} / \mathrm{z}$ of each ion is $-127 \mathrm{~m} / \mathrm{z}$.

\section{Results and discussion}

\subsection{Characterization of mass spectra from SOA and identification of species}

Products in both the gas and condensed phases were identified by analyzing HR-ToF-CIMS data collected under various experimental conditions (Table 1). In each sampling regime, major products were readily identifiable, and only modest or negligible fragmentation occurred with application of the soft ionization technique. The focus in the current work was on condensed-phase products using the FIGAERO inlet desorption. Recently, Stark et al. (2017) showed that fragmentation during the desorption can occur within the FIGAERO. In the current work the fragmentation within the FIGAERO was not specifically investigated. However, from our cluster analysis it was evident that fragmentation occurred with specific features in e.g., molecular weight and evaporation temperature. The ramp rate during desorption was therefore maintained for all experiments to ensure that, if fragmentation did occur, it would be consistent and enable comparable analysis of the dataset. The mass-to-charge $(\mathrm{m} / \mathrm{z}$ or Th) values of the most prominent ions of species detected in the collected aerosol were determined from the average mass spectra obtained during desorption cycles. The results revealed two distinct regions consisting of several clusters of elevated ion signals (Fig. 2). These regions were present in all experiments (Table 1). The occurrence of ions in these regions indicates a prevalence of lower mass monomer species (typically in the range $m / z \quad 340-440$ ) and higher mass dimer species (typically in the range $m / z$ 580-700). These results are analogous to those of previous ozonolysis studies, where highly oxygenated multifunctional (HOM) molecules from monoterpene oxidation were observed using a nitrate HR-ToF-CIMS (Ehn et al., 2014; Jokinen et al., 2015; Mentel et al., 2015). Figure 2 shows an average mass spectrum corresponding to four sequential $1 \mathrm{~h}$ desorption cycles of $12 \mu \mathrm{m}^{-3}$ SOA samples from a reaction mixture with 
a $\mathrm{N}_{2} \mathrm{O}_{5}$ / limonene ratio of 2.4. The gas / particle ratio of most ions was below 1 as illustrated in Fig. S1, whereas the focus of this work was to characterize the particle phase.

In total, 198 of the identified organic ions constituted significant fractions of the aerosol samples, but most of the signal emanated from only $\sim 25 \%$ of these species. The dominant species were identified by averaging the desorption time series of all experiments and extracting the top 75th percentile (by averaging the signal during desorption) of the monomer and dimer ions. The resulting set of ions consisted of 52 molecular species that accounted for $76 \%$ of the organic signal during desorption, while the top 90th percentile of ions (20 ions) accounted for $56 \%$. This 52 ion set consisted of 28 monomers $(C=7-10)$ and 24 dimers or oligomers $(C=11-20)$. From the HR analysis the definition of monomer and dimer was specifically defined based on the number of carbons rather than the less strict definition used for the two $m / z$ regions illustrated in Fig. 2. On average, the top 75th percentile of monomers and the top 75th percentile of dimers accounted for $83 \%$ of the total monomer signal and $70 \%$ of the total dimer signal, respectively. A full list of ions and the composition of the 40th, 75th, and 90th percentile subsets can be found in the Supplement (Table S1). This list is based on a common sensitivity for detection that might not always be true and is highly variable (see e.g., Isaacman-Van Wertz et al., 2017). However, with this assumption the list will provide molecular identity of the most prominent organic compounds contributing to the SOA mass outlined in Table 1. One could assess the contribution of these peaks to the total mass loading, although with high variation in molecular mass and oxidation, the sensitivity is likely to vary significantly, resulting in large error margins and therefore deeming any interpretation highly speculative.

The lower mass region of the two mass-spectra regions (see Fig. 2) typically occurred at $\mathrm{m} / z$ values ranging from 340 to 440 and mainly contained monomers. Several ions in this region matched the predicted molecular formulas associated with the MCM limonene mechanism, and the largest signals occurred for species consisting of 8-10 carbon atoms. For example, the dominant ions occurring at $m / z$ 360, 372, 374 , and 390 (during desorption) corresponded to the iodidecluster ions $\mathrm{C}_{8} \mathrm{H}_{11} \mathrm{NO}_{7} \mathrm{I}^{-}, \mathrm{C}_{10} \mathrm{H}_{15} \mathrm{NO}_{6} \mathrm{I}^{-}, \mathrm{C}_{10} \mathrm{H}_{17} \mathrm{NO}_{6} \mathrm{I}^{-}$, and $\mathrm{C}_{10} \mathrm{H}_{17} \mathrm{NO}_{7} \mathrm{I}^{-}$(Fig. 2a). These correspond to the MCM species C727PAN and C731PAN, C923PAN, NLIMALOH and LIMALNO3, and NLIMALOOH, respectively.

Elevated signals of monomer ions (e.g., $\mathrm{C}_{10} \mathrm{H}_{15} \mathrm{NO}_{7}$ ( $m / z$ 388), $\mathrm{C}_{10} \mathrm{H}_{15} \mathrm{NO}_{8}\left(\mathrm{~m} / z\right.$ 404), $\mathrm{C}_{10} \mathrm{H}_{17} \mathrm{NO}_{8}(\mathrm{~m} / z$ 406), and $\left.\mathrm{C}_{10} \mathrm{H}_{15} \mathrm{NO}_{9}(\mathrm{~m} / z, 420)\right)$, which are absent from the list of expected products of the mechanism, also occurred in this region. These non-MCM species contributed significantly to the total organic monomer signal, and MCM species accounted for only $43.5 \pm 3.2 \%$ of the total monomer signal of all experiments. One common feature of the monomers without a match in MCM is that they contain a nitrogen atom and have an oxygen number higher than 6 , which is a range of compounds that is not represented explicitly in the MCM.

Monomers with progressively more oxygenated monomers of the general formula $\mathrm{C}_{10} \mathrm{H}_{15} \mathrm{NO}_{x}$ were detected for $x=5-9$ e.g., $\mathrm{C}_{10} \mathrm{H}_{15} \mathrm{NO}_{5}-\mathrm{C}_{10} \mathrm{H}_{15} \mathrm{NO}_{9}$, with $\mathrm{C}_{10} \mathrm{H}_{15} \mathrm{NO}_{6}$ being the dominant species in both the aerosol and gas phase in most experiments. Ions with molecular formulas containing two nitrogen atoms, for example, $\mathrm{C}_{10} \mathrm{H}_{16} \mathrm{~N}_{2} \mathrm{O}_{8}\left(m / z\right.$ 419) and $\mathrm{C}_{10} \mathrm{H}_{18} \mathrm{~N}_{2} \mathrm{O}_{8}(m / z 421)$, were also detected (Fig. 2a). Limonene and its primary products only reacted with $\mathrm{NO}_{2}, \mathrm{NO}_{3}^{*}$, and $\mathrm{HNO}_{3}$, yielding molecules that are most likely di-nitrate species, with additional functional groups $\mathrm{F}$.

Similar to the highly oxygenated multi-functional (HOM) species resulting from the ozonolysis of monoterpenes (Ehn et al., 2014; Jokinen et al., 2015), including limonene, many of the observed species could be classified as extremely lowvolatility organic compounds (i.e., ELVOCs), which play a key role in SOA formation (Donahue et al., 2012). Observations performed under ambient conditions during the 2013 Southern Oxidant and Aerosol Study (SOAS) revealed the presence of highly functionalized particulate organic nitrates containing 6-8 oxygen atoms (Lee et al., 2016). In that work, these species constituted 3 and $8 \%$ of sub-micrometer aerosol mass during daytime and nighttime hours, respectively, and exhibited a distinct diurnal pattern, typically reaching peak concentrations between midnight and the early morning hours. The gaseous parent compounds were identified as monoterpenes, matching ions measured in their laboratory study on $\alpha$-pinene, enforcing the importance of monoterpene nitrates in the ambient atmosphere. Complementary, Nah et al. (2016) also measured a large suite of highly oxygenated organic nitrates from $\mathrm{NO}_{3}$ oxidation of $\alpha$-pinene and $\beta$-pinene in laboratory experiments.

For all elevated ion signals above $m / z 390$, there was no corresponding product in the MCM mechanism. As shown in Fig. 2b, zooming into $m / z$ 580-700, illustrating the high mass dimer region, the largest ion signals corresponded to compounds with 19 and 20 carbons in the dimer region. $\mathrm{C}_{20} \mathrm{H}_{22} \mathrm{~N}_{2} \mathrm{O}_{8}$ and $\mathrm{C}_{20} \mathrm{H}_{29} \mathrm{NO}_{17}$, which occurred at significantly elevated levels in all aerosol samples, constituted the lowest and highest mass dimers, respectively (see Fig. 2 for other examples of $\mathrm{C}_{19}$ and $\mathrm{C}_{20}$ dimer species). Many of these can be considered ELVOC species based on their respective formulas and their partitioning behavior (i.e., they were present only in the aerosol phase and at insignificant levels in the gas samples). $\mathrm{C}_{19} \mathrm{H}_{28} \mathrm{~N}_{2} \mathrm{O}_{x}$ and $\mathrm{C}_{20} \mathrm{H}_{29} \mathrm{NO}_{x}$ were the most dominant families of $\mathrm{C}_{19}$ and $\mathrm{C}_{20}$ dimers, respectively. Taken together, 10 individual dimers from these two families were identified in all experiments.

The contributions of the 11 most prevalent ion families (defined as groups of molecular compositions with only the number of $\mathrm{O}$ atoms varying) to the total desorbed organic signal are summarized in Table 2. Average contributions are cal- 
culated from the mean signals for each family relative to the total mean organic signal generated during all experiments.

\subsection{Characterization of identified ions via thermal properties}

The desorption data are characterized by the frequent occurrence of multiple peaks corresponding to certain ions, and the thermograms in all experiments reveal four characteristic desorption patterns, which exhibit the following trends: (i) from 45 to $85^{\circ} \mathrm{C}$, some monomer species undergo almost complete desorption. (ii) Some monomers yield two peaks one in the low-temperature range and another at significantly higher temperatures. Additionally, (iii) some monomer ions, associated with certain individual species of the monomer families, occurred at only very high desorption temperatures, owing possibly to the fragmentation of high-mass oligomers and dimers. (iv) Although less prominent than that observed for monomers, a double peak occurred for several dimers, whereas for other dimers a single primary desorption peak occurred at middle to high temperatures $\left(110-170^{\circ} \mathrm{C}\right)$. The occurrence of multiple peaks is consistent with the thermal degradation of extremely low-volatility species that desorb only at temperatures $>200^{\circ} \mathrm{C}$. Similar behavior has been observed in previous studies (Holzinger et al., 2010; LopezHilfiker et al., 2014, 2015; Yatavelli et al., 2012), where the secondary peaks observed during desorption were attributed to the thermal degradation of very low-volatility aerosol components.

Analysis of the desorption profiles (thermograms) may yield additional information about the properties of each detected chemical species. The gradual heating of the FIGAERO filter from 25 to $200^{\circ} \mathrm{C}$ resulted in a clear volatilitybased separation of species and, for each ion detected, the desorption temperature corresponding to the maximum signal was identified. Furthermore, the average desorption temperature of the monomer species was typically lower than that of their dimer counterparts, which are less volatile. Higher masses (than those associated with the monomer species) were typically desorbed from the FIGAERO filter at higher temperatures. An example of this characteristic behavior is shown in the average thermograms (Fig. 3) of several monomer and dimer ions. In general, compounds evaporating at relatively low temperatures were also found in the gas phase, indicative of monomers that partition between the gas and particle phase.

As shown in Fig. 3, each of the detected ion signals reaches at least one local maximum value. The temperature at which a signal reached the first maximum $\left(T_{\max }\right)$ value was similar across all experiments (the average standard deviation was $<10 \%$ ). Secondary peaks occurred more frequently for species with a carbon number of 10 or lower, consistent with a degradation-based contribution. Although the temperature at which the secondary local maximum occurs $\left(T_{\max , 2}\right)$ provides insight into the occurrence of dimerization, the $T_{\max }$ value was taken as the true desorption temperature of each ion.

$T_{\max }$ values were identified for each ion in the 196 ion set. Monomer, i.e., lower mass, species $(\mathrm{C} \leq 10)$ desorbing at high temperatures could be produced as fragments via thermal degradation of higher MW species. Some of these ions match the chemical composition $\left(\mathrm{C}_{10} \mathrm{H}_{16} \mathrm{O}_{4}, \mathrm{C}_{10} \mathrm{H}_{17} \mathrm{NO}_{5}\right.$, $\mathrm{C}_{10} \mathrm{H}_{17} \mathrm{NO}_{6}$, and $\mathrm{C}_{7} \mathrm{H}_{10} \mathrm{O}_{4}$ ) of primary products within the MCM, accounting for (on average) $69.0 \pm 10.8 \%$ of the signal detected in the gas phase. Here some possibilities are plausible; one could be that they are produced as monomer but are important building blocks in the dimer formation, thus thermally decompose back to monomers during desorption.

The ratio of dimers/monomers varied between experiments. At high ratios of $\mathrm{N}_{2} \mathrm{O}_{5} /$ limonene, the fraction of dimer species decreased relative to the total organic signal, whereas the percentage of high-temperature desorbing monomer species (fragments) increased (Fig. 4). This suggests that absolute dimer formation may have remained the same, but the monomer signal is overrepresented by monomer fragments generated from high-mass, thermally unstable compounds. This percentage is calculated based on the assumption of a common detection sensitivity across all ions; this assumption may influence the estimated (percentage) contribution of monomers relative to that of dimers.

\subsection{Characterization of major SOA products via cluster analysis}

Clustering was performed on an ion set consisting of 117 ions, which accounted for $>90 \%$ of the total organic signal generated during desorption in all experiments. Ions generating extremely low signal (e.g., the thermogram did not exhibit any structure identifiable above background noise, prohibiting Tofware to constrain a mathematical fit for $T_{\max }$ calculations) were excluded to prevent analysis of ions with misidentified $T_{\max }$ values. However, the occurrence of hightemperature desorbing monomer outliers (described previously) and the double-peak behavior exhibited by several monomers rendered the mass- and temperature-based grouping of these ions difficult. To address this issue, duplicate entries, corresponding to $T_{\max }$ and $T_{\max , 2}$, were assigned to all ions exhibiting double-peak behavior, allowing the clear separation and analysis of low-mass ions desorbing at temperatures $>120^{\circ} \mathrm{C}$.

Four and five clusters $\left(\#_{\text {clust }}=\{4,5\}\right)$, using $T_{\max }$, MW, and carbon number as input, yielded the best $T_{\max }$-based clustering and separation of ions. The use of $n_{\mathrm{H}}$ and $n_{\mathrm{O}}$ as additional input parameters resulted in partial separation of clusters into groups with similar $\mathrm{O} / \mathrm{C}$ and $\mathrm{H} / \mathrm{C}$ ratios and poor correlations with respect to $T_{\max }$. The average silhouette score obtained for four clusters was better ( 0.81 vs. 0.72 ) than that obtained for five clusters. However, the use of five clusters allowed for the separation of low-temperature des- 


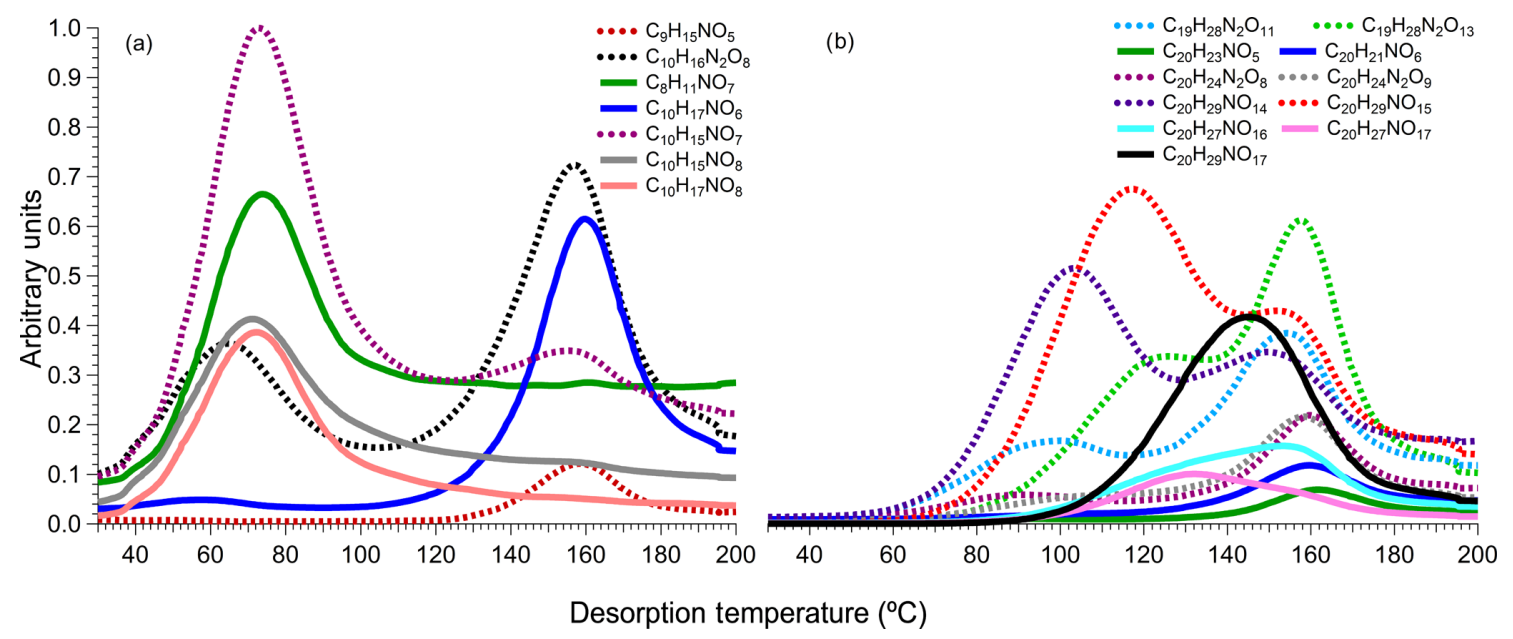

Figure 3. Average thermograms (over four desorption cycles) for an $\mathrm{N}_{2} \mathrm{O}_{5}$ ratio of 2.4. Thermograms of ion clusters of the (a) monomer species $\left(\mathrm{C}_{8}-\mathrm{C}_{10}\right)$ and (b) dimer $\left(\mathrm{C}_{19}-\mathrm{C}_{20}\right)$ species. Ions with double-peak thermogram shape patterns, consistent with the fragmentation of low-volatility oligomers, are shown as dashed lines.

Table 2. Peak desorption temperature $\left(T_{\max }\right)$ and the average contribution (over all experiments) to the organic signal during SOA desorption for the most commonly observed product families. The number of monomer species in each family that desorbed at only high temperatures is noted in parentheses.

\begin{tabular}{lllrrr}
\hline Class & No. & Family & $\begin{array}{r}\text { No. observed } \\
\text { in family }\end{array}$ & $\begin{array}{r}\text { Average } \\
\text { contribution }\end{array}$ & $\begin{array}{r}T_{\text {max }} \text { range } \\
\left({ }^{\circ} \mathrm{C}\right)\end{array}$ \\
\hline Monomers & $\mathrm{m} 1$ & $\mathrm{C}_{10} \mathrm{H}_{15} \mathrm{NO}_{x}$ & $5(1)$ & $23.0 \pm 8.0 \%$ & $74-152$ \\
& $\mathrm{~m} 2$ & $\mathrm{C}_{10} \mathrm{H}_{18} \mathrm{~N}_{2} \mathrm{O}_{x}$ & $2(0)$ & $8.8 \pm 2.4 \%$ & $66-70$ \\
& $\mathrm{~m} 3$ & $\mathrm{C}_{10} \mathrm{H}_{16} \mathrm{~N}_{2} \mathrm{O}_{x}$ & $5(1)$ & $6.7 \pm 2.2 \%$ & $52-154$ \\
& $\mathrm{~m} 4$ & $\mathrm{C}_{10} \mathrm{H}_{17} \mathrm{NO}_{x}$ & $5(2)$ & $5.3 \pm 2.7 \%$ & $59-159$ \\
& $\mathrm{~m} 5$ & $\mathrm{C}_{8} \mathrm{H}_{11} \mathrm{NO}_{x}$ & $3(0)$ & $4.7 \pm 1.4 \%$ & $68-81$ \\
& $\mathrm{~m} 6$ & $\mathrm{C}_{9} \mathrm{H}_{13} \mathrm{NO}_{x}$ & $4(0)$ & $3.0 \pm 1.1 \%$ & $70-75$ \\
& $\mathrm{~m} 7$ & $\mathrm{C}_{9} \mathrm{H}_{15} \mathrm{NO}_{x}$ & $4(0)$ & $2.0 \pm 0.7 \%$ & $64-76$ \\
\hline \multirow{2}{*}{ Dimers } & $\mathrm{d} 1$ & $\mathrm{C}_{20} \mathrm{H}_{29} \mathrm{NO}_{x}$ & 4 & $7.1 \pm 3.3 \%$ & $100-154$ \\
& $\mathrm{~d} 2$ & $\mathrm{C}_{19} \mathrm{H}_{28} \mathrm{~N}_{2} \mathrm{O}_{x}$ & 6 & $5.0 \pm 2.2 \%$ & $101-157$ \\
& $\mathrm{~d} 3$ & $\mathrm{C}_{20} \mathrm{H}_{27} \mathrm{NO}_{x}$ & 4 & $2.8 \pm 1.2 \%$ & $101-151$ \\
& $\mathrm{~d} 4$ & $\mathrm{C}_{20} \mathrm{H}_{24} \mathrm{~N}_{2} \mathrm{O}_{x}$ & 3 & $2.0 \pm 1.7 \%$ & $125-157$ \\
\hline
\end{tabular}

orbing monomers into two groups with distinct average $T_{\max }$ and MW with smaller differences in $\mathrm{O} / \mathrm{C}$ ratios and oxidation states $(2 \times \mathrm{O} / \mathrm{C}-\mathrm{H} / \mathrm{C}-5 \times \mathrm{N} / \mathrm{C})$. Using more than five clusters resulted in a further decrease in the quality of cluster separation, as measured by the inertia (Eq. 1) and average silhouette score (Eq. 2). Although the identification of subgroups within each cluster is possible by increasing \# $\#_{\text {clust }}$, the five main clusters were chosen based on their separation by mass and $T_{\max }$ values to reduce complexity of the interpretation of the resulting clusters with respect to the chemical composition.

Figure 5a shows the cluster separation on the MW- $T_{\max }$ plane. The distribution of individual cluster members is based on oxidation states and carbon number (Fig. 5b), and the mean $\mathrm{MW}, T_{\max }, \mathrm{O} / \mathrm{C}$, and oxidation state of each cluster (Fig. 5c) are also shown.
As Fig. 5 shows, the five clusters are characterized by distinct average MWs and corresponding average $T_{\max }$ values. Cluster 0 consists of monomer ions, which are considered fragments of larger, less-volatile molecules that desorb at high temperatures. The average oxidation state and $\mathrm{O} / \mathrm{C}$ ratio are similar to those of clusters 1 and 2 , which are composed primarily of C7-C9 and C9-C10 monomer ions, respectively. This results from the fact that 87 and $69 \%$ of cluster 1 and 2 ions, respectively, have secondary thermogram peaks and $T_{\max }$ values, and the ions were represented as members of both clusters 1 and 0 . Ions corresponding to the identified dimers are contained in clusters 3 and 4 . The dimers are characterized by two primary desorption regimes, with species that desorb at mid-range temperatures $\left(80-130^{\circ} \mathrm{C}\right)$ occurring in cluster 3 and the highestmass, lowest-volatility ions occurring in cluster 4 . Moreover, 


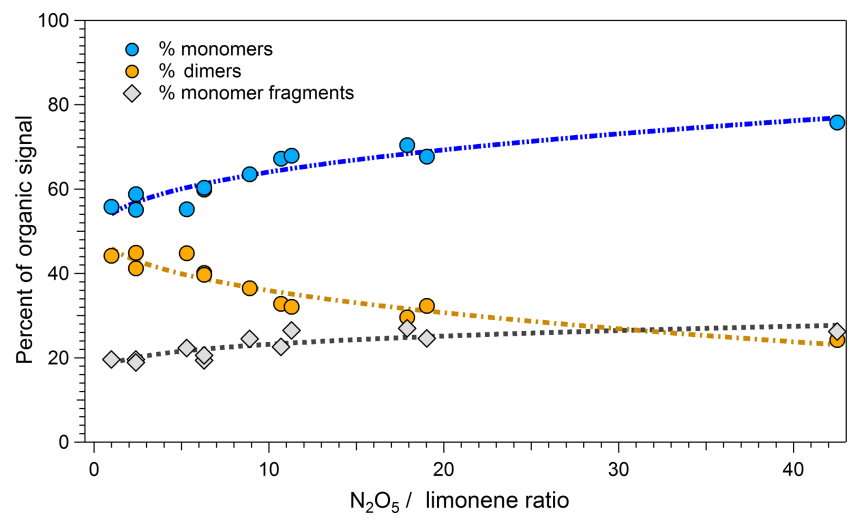

Figure 4. Percentage of monomer, dimer, and high-temperature monomer signal (observed during desorption) relative to the ratio of $\mathrm{N}_{2} \mathrm{O}_{5}$ / limonene injected into the reactor. The data points at a ratio of 113 are not shown $(22,78,39 \%$, respectively). The lines indicated are for the guidance of the eye.

the distribution of individual cluster members with respect to carbon number and oxidation state (Fig. 5b) shows that members of low-MW clusters $(0,1,2)$ and high-MW clusters $(3,4)$ reside in separate regimes. The ions in high-MW clusters have a significantly larger number of carbon atoms per molecule and, hence, lower (on average) oxidation states than ions in clusters $0-2$. With respect to the most prevalent families listed in Table 2, monomer families $\mathrm{m} 2, \mathrm{~m} 3$, and $\mathrm{m} 4$ reside exclusively in cluster 2 , whereas $\mathrm{m} 5$ and $\mathrm{m} 7$ reside exclusively in cluster 1 . Family members of $\mathrm{m} 1$ and $\mathrm{m} 6$ were split $20 / 80$ and $75 / 25 \%$ between clusters 1 and 2, respectively. Dimer families d1-d4 occurred predominantly (66$75 \%$ ) in cluster 4 , with the remainder residing in cluster 3. None of the dimer families in Table 2 occurred in clusters 0 , 1 or 2 .

A positive trend between the MW and $T_{\max }$ values (see Fig 5a) was obtained for data in two of the monomer clusters (1 and 2) and the high volatile dimer cluster, while the trend turned negative for the low volatile dimer cluster. It should be noted that monomer species had (in general) higher $\mathrm{O} / \mathrm{C}$ ratios than the dimers. It could be that monomers need more oxidation before being transferred into the condensed phase. However, as outlined by the partitioning plots (Fig. S1) most monomers also have a significant condensed-phase contribution. Rather, this observation provides some insight into the processes of dimerization that are occurring, indicating the extent to which oxygen is lost during the dimerization process.

\subsection{Mechanisms of dimerization}

The mechanism to create dimers with one nitrogen and a lower O / C ratio would presumably involve the loss of nitrogen oxides or nitric acid. For this complex system and within the scope of this study it was not possible to firmly prove any mechanism. Since the experiments were done at low $\mathrm{RH}$ the direct hydrolysis would be less likely (see Rindelaub et al, 2015, 2016). However, knowing $\mathrm{HNO}_{3}$ is thermodynamically stable, one may speculate that dimerization of two monomer species via the loss of one $\mathrm{HNO}_{3}$ molecule could occur e.g., where a $\mathrm{C}_{20} \mathrm{H}_{29} \mathrm{NO}_{y}(y=7-15)$ species would be generated from $\mathrm{C}_{10} \mathrm{H}_{15} \mathrm{NO}_{x}(x=5-9)$ species. This process could be seen as the reverse of esterification in order to produce a dimer product with one less nitrogen atom and a reduced number of oxygen atoms. For example, with $\mathrm{HNO}_{3}$ as a leaving group, the mechanism of dimerization between $\mathrm{C}_{10} \mathrm{H}_{15} \mathrm{NO}_{6}$ and $\mathrm{C}_{10} \mathrm{H}_{15} \mathrm{NO}_{8}$ (see Reaction 3) would produce the $\mathrm{C}_{20}$ dimer species $\left(\mathrm{C}_{20} \mathrm{H}_{29} \mathrm{NO}_{11}\right)$ that was observed in all experiments. The formation of the observed $\mathrm{C}_{19}$ dimer species (e.g., $\mathrm{C}_{19} \mathrm{H}_{27} \mathrm{O}_{15}$ ) through the combination of, for example, $\mathrm{C}_{10} \mathrm{H}_{17} \mathrm{NO}_{7}$ and $\mathrm{C}_{9} \mathrm{H}_{11} \mathrm{NO}_{11}$ monomer species (Reaction 4) is also attributed to this mechanism. Additionally, the occurrence of dimer species with two nitrogen atoms, through the combination of monomers such as $\mathrm{C}_{10} \mathrm{H}_{16} \mathrm{~N}_{2} \mathrm{O}_{9}$ and $\mathrm{C}_{9} \mathrm{H}_{13} \mathrm{NO}_{8}$ (Reaction 5), can also be attributed to this dimerization mechanism.

$$
\begin{aligned}
& \mathrm{C}_{10} \mathrm{H}_{15} \mathrm{NO}_{6}+\mathrm{C}_{10} \mathrm{H}_{15} \mathrm{NO}_{8} \rightarrow \mathrm{C}_{20} \mathrm{H}_{29} \mathrm{NO}_{11}+\mathrm{HNO}_{3} \\
& \mathrm{C}_{10} \mathrm{H}_{17} \mathrm{NO}_{7}+\mathrm{C}_{9} \mathrm{H}_{11} \mathrm{NO}_{11} \rightarrow \mathrm{C}_{19} \mathrm{H}_{27} \mathrm{NO}_{15}+\mathrm{HNO}_{3} \\
& \mathrm{C}_{10} \mathrm{H}_{16} \mathrm{~N}_{2} \mathrm{O}_{9}+\mathrm{C}_{9} \mathrm{H}_{13} \mathrm{NO}_{8} \rightarrow \mathrm{C}_{19} \mathrm{H}_{28} \mathrm{~N}_{2} \mathrm{O}_{14}+\mathrm{HNO}_{3}
\end{aligned}
$$

The higher $\mathrm{O} / \mathrm{C}$ ratios of the monomer species, compared with those of the dimers/oligomers, may also be attributed to the loss of an $\mathrm{HNO}_{3}$ molecule (from the monomer) during the dimerization process. For example, the two $\mathrm{C}_{10}$ reactants in Reaction (3) have $\mathrm{O} / \mathrm{C}$ ratios of 0.6 and 0.8 , while the product, $\mathrm{C}_{20} \mathrm{H}_{29} \mathrm{NO}_{11}$, has an $\mathrm{O} / \mathrm{C}$ ratio of 0.55. A similar trend is observed for Reactions (4) and (5), where the reactants have an average $\mathrm{O} / \mathrm{C}$ ratio of 0.96 and 0.89 , respectively, and the products have $\mathrm{O} / \mathrm{C}$ ratios of 0.79 and 0.74 , respectively. Due to the loss of $\mathrm{HNO}_{3}$ during dimerization, the potential dimer decomposition during desorption is expected to yield fragments which differ in molecular composition from the precursor (i.e., pre-dimerization) monomers. However, the resulting monomers may also be associated with aerosol-phase products that have secondary desorption peaks. For example, the fragmentation of $\mathrm{C}_{20} \mathrm{H}_{29} \mathrm{NO}_{11}$ could yield $\mathrm{C}_{10} \mathrm{H}_{14} \mathrm{O}_{6}+\mathrm{C}_{10} \mathrm{H}_{15} \mathrm{NO}_{5}$ or $\mathrm{C}_{10} \mathrm{H}_{16} \mathrm{O}_{5}+\mathrm{C}_{10} \mathrm{H}_{13} \mathrm{NO}_{6}$, and the fragmentation of $\mathrm{C}_{19} \mathrm{H}_{27} \mathrm{NO}_{15}$ might yield $\mathrm{C}_{9} \mathrm{H}_{13} \mathrm{NO}_{6}+\mathrm{C}_{10} \mathrm{H}_{14} \mathrm{O}_{9}$ or $\mathrm{C}_{9} \mathrm{H}_{13} \mathrm{NO}_{9}+\mathrm{C}_{10} \mathrm{H}_{14} \mathrm{O}_{6}$. Likewise, $\mathrm{C}_{9} \mathrm{H}_{13} \mathrm{NO}_{7}+\mathrm{C}_{10} \mathrm{H}_{15} \mathrm{NO}_{7}$ or $\mathrm{C}_{9} \mathrm{H}_{13} \mathrm{NO}_{9}+\mathrm{C}_{10} \mathrm{H}_{15} \mathrm{NO}_{5}$ monomer pairs could be generated from the thermal degradation of $\mathrm{C}_{19} \mathrm{H}_{28} \mathrm{~N}_{2} \mathrm{O}_{14}$.

The fragmentation of dimers may also proceed through multiple channels, thereby producing several sets of monomer fragments, or the fragmentation of multiple dimers may produce the same ions. Therefore, attributing the production of a monomer fragment to the thermal degradation of a specific dimer is difficult using the current dataset. 

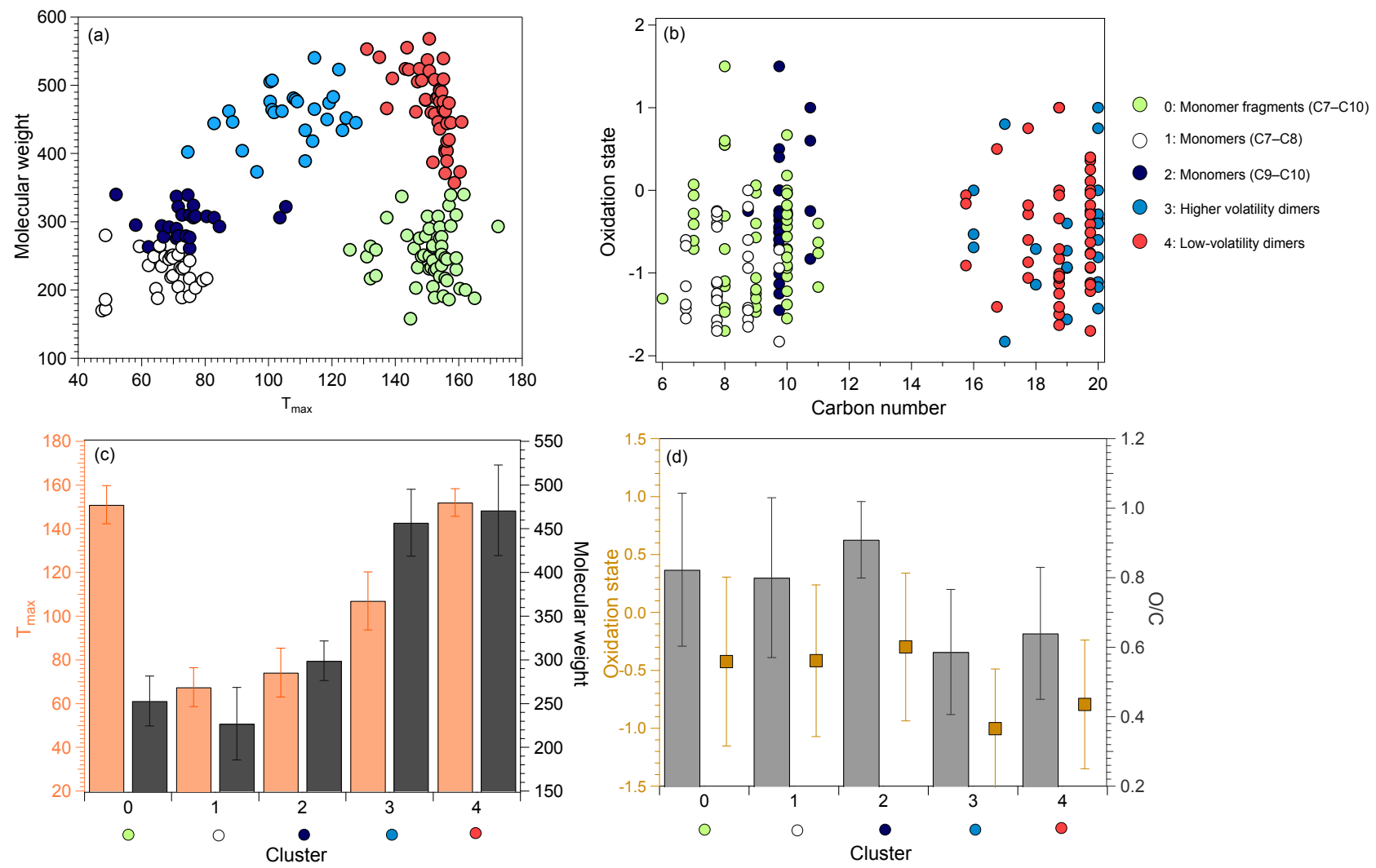

Figure 5. Characteristics of the five identified clusters: (a) desorption temperature of each observed ion in the top 40th percentile of ions (identified by their respective desorption signal), color-coded by their corresponding cluster number, (b) oxidation state relative to carbon number of all observed ions, colored by their corresponding cluster membership (for visualization purposes, carbon numbers of groups 0,2 , and 4 are offset), (c) average cluster mass and desorption temperature, and (d) average cluster oxidation state and $\mathrm{O} / \mathrm{C}$ ratios. Error bars in panels (c) and (d) indicate standard deviations for each cluster property.

Large $(\mathrm{C}>20)$ oligomeric species may contribute to the hightemperature generation of monomer fragment species. The proposed mechanisms may play only a partial role in the dimerization process occurring in these experiments. However, they offer a plausible explanation for the occurrence of multiple observed dimers and the secondary desorption maxima associated with the monomer constituents.

\section{Conclusions}

High-resolution mass spectrometric data were analyzed for condensed-phase reaction products resulting from $\mathrm{NO}_{3}$ initiated oxidation of the monoterpene, limonene. The results revealed that the formation of organic nitrates contributed substantially ( $89.5 \pm 1.4 \%$ of the particulate-phase ion signal) to SOA formation, with dimers constituting a significant fraction of the particle-phase products. On average, monomers and dimers/oligomers contributed $63 \pm 7$ and $37 \pm 7 \%$, respectively, of the particle-phase organic signal detected by the I-CIMS. Furthermore, many monomers (accounting for $22 \pm 3 \%$ of the average organic signal) desorbed at high tem- peratures $\left(120^{\circ} \mathrm{C}\right)$. The fraction of the signal generated by monomers increased with increasing $\mathrm{N}_{2} \mathrm{O}_{5}$ / limonene ratio (ratio of 43 yields a fraction of $76 \%$ ), whereas the fraction of dimers decreased (to $24 \%$ ). The fraction of the monomer signal resulting from desorption at high temperatures $\left(\geq 120^{\circ} \mathrm{C}\right)$ also increased (by $26 \%$ ). Therefore, although the monomer fraction increased with increasing $\mathrm{N}_{2} \mathrm{O}_{5}$ / limonene ratio, this increase in desorption signal occurred primarily at temperatures above $120^{\circ} \mathrm{C}$, indicative of an increase in the fragmentation of high-MW dimers and oligomers. A large portion $(79 \%)$ of the monomer thermograms exhibited this bimodal behavior, with secondary peaks occurring above $120^{\circ} \mathrm{C}$, indicating that the composition of SOA was largely determined by the formation of thermally unstable, lowvolatility oligomers.

In total, 196 individual organic ions were detected during desorption. However, the total measured organic signal was generated mainly by 52 (i.e., $76 \%$ ) of these ions, which constituted the 75th percentile of the monomer and dimer signals. Over half of the signal emanated from the top 90th percentile, which comprised a small subset of only 20 species, 
of the total number of ions. These 20 species (with nine listed as major products in the MCM) constituted the major particle-phase products formed via the reaction of $\mathrm{N}_{2} \mathrm{O}_{5}$ and limonene under the conditions employed in this study. The non-listed species (see Table S1) were either dimer species or more highly oxygenated, nitrated analogs of known major products, which are notoriously hard to describe via standard gas-phase mechanisms. There are two frequently suggested pathways for these. Firstly, the high number of oxygen atoms would be the result of isomerization of $\mathrm{RO}$ or $\mathrm{RO}_{2}$ that is rarely described explicitly in current modeling framework. Secondly, the presence of di-nitrated compounds relies on secondary chemistry derived from, e.g., mononitrate intermediates produced; for limonene containing two double bonds this is more relevant than for other monoterpenes and is so far not commonly described in models.

Cluster analysis revealed two monomer groups, two dimer groups, and a separate group containing monomer ions that exhibited secondary desorption peaks occurring at temperatures $\geq 150^{\circ} \mathrm{C}$. Each group was characterized by a distinct average MW and desorption temperature $\left(T_{\max }\right)$. The two identified clusters in the monomer and dimer sub-classes differ in oxidation state and $\mathrm{O} / \mathrm{C}$ ratios, with increasing $\mathrm{O} / \mathrm{C}$ corresponding to higher $T_{\max }$ values.

Using a combination of cluster analysis and thermal properties derived from FIGAERO-CIMS measurements may provide some means of reducing the complexity associated with the description of SOA formation processes. The investigated reaction system constitutes only one of many systems, but could be used as an example of the evaluation required for this type of information derived from highresolution MS. The results revealed that, analogous to products from ozonolysis and ${ }^{\cdot} \mathrm{OH}$-induced oxidation, the organic nitrates produced in the nighttime chemistry of biogenic compounds comprise a multi-component mixture that contributes to ambient SOA. Thus, the aerosol species detected here could be included in modeling studies with the aim of explaining scenarios where SOA formation rates are underpredicted. Furthermore, the numerous products resulting from $\mathrm{NO}_{3}$ oxidation of limonene, which were identified and grouped based on thermal properties, could be candidates for identification in ambient air masses dominated by nocturnal limonene chemistry.

Data availability. The underlying data for this study have been reposited at the Swedish National Data Service (https://doi.org/10. 5878/002983).

The Supplement related to this article is available online at https://doi.org/10.5194/acp-18-5467-2018-supplement.
Competing interests. The authors declare that they have no conflict of interest.

Acknowledgements. The research presented is a contribution to the Swedish strategic research area ModElling the Regional and Global Earth system, MERGE. This work was supported by the Swedish Research Council (grant numbers 2015-04123; 2014-05332; 2013-06917) and Formas (grant number 2015-1537).

Edited by: Astrid Kiendler-Scharr

Reviewed by: three anonymous referees

\section{References}

Arthur, D. and Vassilvitskii, S.: k-means ++: The advantages of careful seeding, ACM-SIAM Symp. Discret. algorithms, 8, 1027-1035, 2007.

Atkinson, R., Aschmann, S. M., and Pitts, J. N. J.: Rate constants for the gas-phase reactions of the $\mathrm{OH}$ radical with a series of monoterpenes at $294 \mathrm{~K}$, Atmos. Environ., 29, 2311-2316

Ayres, B. R., Allen, H. M., Draper, D. C., Brown, S. S., Wild, R. J., Jimenez, J. L., Day, D. A., Campuzano-Jost, P., Hu, W., de Gouw, J., Koss, A., Cohen, R. C., Duffey, K. C., Romer, P., Baumann, K., Edgerton, E., Takahama, S., Thornton, J. A., Lee, B. H., Lopez-Hilfiker, F. D., Mohr, C., Goldstein, A. H., Olson, K., and Fry, J. L.: Organic nitrate aerosol formation via $\mathrm{NO}_{3}+\mathrm{BVOC}$ in the Southeastern US, Atmos. Chem. Phys. Discuss., 15, 1623516272, https://doi.org/10.5194/acpd-15-16235-2015, 2015.

Baptista, L., Pfeifer, R., Da Silva, E. C., and Arbilla, G.: Kinetics and thermodynamics of limonene ozonolysis, J. Phys. Chem. A, 115, 10911-10919, https://doi.org/10.1021/jp205734h, 2011.

Beaver, M. R., Clair, J. M. St., Paulot, F., Spencer, K. M., Crounse, J. D., LaFranchi, B. W., Min, K. E., Pusede, S. E., Wooldridge, P. J., Schade, G. W., Park, C., Cohen, R. C., and Wennberg, P. O.: Importance of biogenic precursors to the budget of organic nitrates: Observations of multifunctional organic nitrates by CIMS and TD-LIF during BEARPEX 2009, Atmos. Chem. Phys., 12, 5773-5785, https://doi.org/10.5194/acp-12-5773-2012, 2012.

Bonn, B. and Moorgat, G. K.: New particle formation during a- and b-pinene oxidation by $\mathrm{O}_{3}, \mathrm{OH}$ and $\mathrm{NO}_{3}$, and the influence of water vapour: Particle size distribution studies, Atmos. Chem. Phys., 2, 183-196, https://doi.org/10.5194/acp-2183-2002, 2002.

Boyd, C. M., Nah, T., Xu, L., Berkemeir, T., and Lee Ng, N.: Secondary Organic Aerosol (SOA) from nitrate radical oxidation of monoterpenes: Efftecs of temperature, dilution and humidity on aeorosol formations, mixing, and evaporation, Environ. Sci. Technol., 51, 7831-7841, 2017.

Brown, S. S. and Stutz, J.: Nighttime radical observations and chemistry, Chem. Soc. Rev., 41, 6405, https://doi.org/10.1039/c2cs35181a, 2012.

Bruns, E. A, Perraud, V., Zelenyuk, A., Ezell, M. J., Johnson, S. N., Yu, Y., Imre, D., Finlayson-Pitts, B. J., and Alexander, M. L.: Comparison of FTIR and particle mass spectrometry for the measurement of particulate organic nitrates, Environ. Sci. Technol., 44, 1056-1061, https://doi.org/10.1021/es9029864, 2010. 
Cao, G. and Jang, M.: Secondary organic aerosol formation from toluene photooxidation under various $\mathrm{NO}_{x}$ conditions and particle acidity, Atmos. Chem. Phys. Discuss., 8, 14467-14495, https://doi.org/10.5194/acpd-8-14467-2008, 2008.

Carlton, A. G., Wiedinmyer, C., and Kroll, J. H.: A review of Secondary Organic Aerosol (SOA) formation from isoprene, Atmos. Chem. Phys., 9, 4987-5005, https://doi.org/10.5194/acp-9-49872009, 2009.

Day, D. A., Liu, S., Russell, L. M., and Ziemann, P. J.: Organonitrate group concentrations in submicron particles with high nitrate and organic fractions in coastal southern California, Atmos. Environ., 44, 1970-1979, 2010.

Donahue, N. M., Kroll, J. H., Pandis, S. N., and Robinson, A. L.: A two-dimensional volatility basis set - Part 2: Diagnostics of organic-aerosol evolution, Atmos. Chem. Phys., 12, 615-634, https://doi.org/10.5194/acp-12-615-2012, 2012.

Ehn, M., Thornton, J. A., Kleist, E., Sipilä, M., Junninen, H., Pullinen, I., Springer, M., Rubach, F., Tillmann, R., Lee, B., Lopez-Hilfiker, F., Andres, S., Acir, I.-H., Rissanen, M., Jokinen, T., Schobesberger, S., Kangasluoma, J., Kontkanen, J., Nieminen, T., Kurtén, T., Nielsen, L. B., Jørgensen, S., Kjaergaard, H. G., Canagaratna, M., Maso, M. D., Berndt, T., Petäjä, T., Wahner, A., Kerminen, V.-M., Kulmala, M., Worsnop, D. R., Wildt, J., and Mentel, T. F.: A large source of lowvolatility secondary organic aerosol, Nature, 506, 476-479, https://doi.org/10.1038/nature13032, 2014.

Emanuelsson, E. U., Hallquist, M., Kristensen, K., Glasius, M., Bohn, B., Fuchs, H., Kammer, B., Kiendler-Scharr, A., Nehr, S., Rubach, F., Tillmann, R., Wahner, A., Wu, H. C., and Mentel, T. F.: Formation of anthropogenic secondary organic aerosol (SOA) and its influence on biogenic SOA properties, Atmos. Chem. Phys., 13, 2837-2855, https://doi.org/10.5194/acp-132837-2013, 2013.

Fry, J. L., Rollins, A. W., Wooldridge, P. J., Brown, S. S., Fuchs, H., and Dub, W.: Organic nitrate and secondary organic aerosol yield from $\mathrm{NO}_{3}$ oxidation of â-pinene evaluated using a gas-phase kinetics/aerosol partitioning model, Atmos. Chem. Phys., 9, 14311449, https://doi.org/10.5194/acp-9-1431-2009, 2009.

Fry, J. L., Kiendler-Scharr, A., Rollins, A. W., Brauers, T., Brown, S. S., Dorn, H.-P., Dubé, W. P., Fuchs, H., Mensah, A., Rohrer, F., Tillmann, R., Wahner, A., Wooldridge, P. J., and Cohen, R. C.: SOA from limonene: role of $\mathrm{NO}_{3}$ in its generation and degradation, Atmos. Chem. Phys., 11, 3879-3894, https://doi.org/10.5194/acp-11-3879-2011, 2011.

Fry, J. L., Draper, D. C., Barsanti, K. C., Smith, J. N., Ortega, J., Winkler, P. M., Lawler, M. J., Brown, S. S., Edwards, P. M., Cohen, R. C., and Lee, L.: Secondary organic aerosol formation and organic nitrate yield from $\mathrm{NO}_{3}$ oxidation of biogenic hydrocarbons, Environ. Sci. Technol., 48, 11944-11953, 2014.

Glasius, M. and Goldstein, A. H.: Recent discoveries and future challenges in atmospheric organic chemistry, Environ. Sci. Technol., 50, 2754-2764, https://doi.org/10.1021/acs.est.5b05105, 2016.

Guenther, A., Nicholas, C., Erickson, D., Fall, R., Geron, C., Graedel, T., Harley, P., Klinger, L., Lerdau, M., Mckay, W. A., Pierce, T., Scholes, B., Steinbrecher, R., Tallamraju, R., Taylor, J., and Zimmerman, P.: A global model of natural volatile organic compound emissions, J. Geophys. Res., 100, 8873-8892, 1995.
Guenther, A., Karl, T., Harley, P., Wiedinmyer, C., Palmer, P. I., and Geron, C.: Estimates of global terrestrial isoprene emissions using MEGAN (Model of Emissions of Gases and Aerosols from Nature), Atmos. Chem. Phys., 6, 3181-3210, https://doi.org/10.5194/acp-6-3181-2006, 2006.

Guenther, A. B., Jiang, X., Heald, C. L., Sakulyanontvittaya, T., Duhl, T., Emmons, L. K., and Wang, X.: The model of emissions of gases and aerosols from nature version 2.1 (MEGAN2.1): An extended and updated framework for modeling biogenic emissions, Geosci. Model Dev., 5, 1471-1492, https://doi.org/10.5194/gmd-5-1471-2012, 2012.

Hallquist, M., Wängberg, I., Ljungström, E., Barnes, I., and Becker, K. H.: Aerosol and product yields from $\mathrm{NO}_{3}$ radical-initiated oxidation of selected monoterpenes, Environ. Sci. Technol., 33, 553-559, https://doi.org/10.1021/es980292s, 1999.

Hallquist, M., Wenger, J. C., Baltensperger, U., Rudich, Y., Simpson, D., Claeys, M., Dommen, J., Donahue, N. M., George, C., Goldstein, A. H., Hamilton, J. F., Herrmann, H., Hoffmann, T., Iinuma, Y., Jang, M., Jenkin, M. E., Jimenez, J. L., KiendlerScharr, A., Maenhaut, W., McFiggans, G., Mentel, T. F., Monod, A., Prévôt, A. S. H., Seinfeld, J. H., Surratt, J. D., Szmigielski, R., and Wildt, J.: The formation, properties and impact of secondary organic aerosol: current and emerging issues, Atmos. Chem. Phys., 9, 5155-5236, https://doi.org/10.5194/acp-9-51552009, 2009.

Holzinger, R., Kasper-Giebl, A., Staudinger, M., Schauer, G., and Röckmann, T.: Analysis of the chemical composition of organic aerosol at the Mt. Sonnblick observatory using a novel high mass resolution thermal-desorption proton-transfer-reaction mass-spectrometer (HR-TD-PTR-MS), Atmos. Chem. Phys., 10, 10111-10128, https://doi.org/10.5194/acp-10-10111-2010, 2010.

Jiang, L., Lan, R., Xu, Y. S., Zhang, W. J., and Yang, W.: Reaction of stabilized criegee intermediates from ozonolysis of limonene with water: Ab initio and DFT study, Int. J. Mol. Sci., 14, 5784 5805, https://doi.org/10.3390/ijms14035784, 2013.

Jimenez, J. L., Canagaratna, M. R., Donahue, N. M., Prevot, A. S. H., Zhang, Q., Kroll, J. H., Decarlo, P. F., Allan, J. D., Coe, H., Ng, N. L., Aiken, A. C., Ulbrich, I. M., Grieshop, A. P., Duplissy, J., Wilson, K. R., Lanz, V. A., Hueglin, C., Sun, Y. L., Tian, J., Laaksonen, A., Raatikainen, T., Rautiainen, J., Vaattovaara, P., Ehn, M., Kulmala, M., Tomlinson, J. M., Cubison, M. J., Dunlea, E. J., Alfarra, M. R., Williams, P. I., Bower, K., Kondo, Y., Schneider, J., Drewnick, F., Borrmann, S., Weimer, S., Demerjian, K., Salcedo, D., Cottrell, L., Takami, A., Miyoshi, T., Shimono, A., Sun, J. Y., Zhang, Y. M., Dzepina, K., Sueper, D., Jayne, J. T., Herndon, S. C., Williams, L. R., Wood, E. C., Middlebrook, A. M., Kolb, C. E., Baltensperger, U., and Worsnop, D. R.: Evolution of organic aerosols in the atmosphere, Science 326, 1525-1529, 2006.

Jokinen, T., Berndt, T., Makkonen, R., Kerminen, V.-M., Junninen, H., Paasonen, P., Stratmann, F., Herrmann, H., Guenther, A. B., Worsnop, D. R., Kulmala, M., Ehn, M., and Sipilä, M.: Production of extremely low volatile organic compounds from biogenic emissions: Measured yields and atmospheric implications, P. Natl. Acad. Sci. USA, 112, 7123-7128, https://doi.org/10.1073/pnas.1423977112, 2015.

Jonsson, A. M., Hallquist, M., and Ljungström, E.: Impact of humidity on the ozone initiated oxidation of limonene, Ä3- 
carene, and $\alpha$-pinene, Environ. Sci. Technol., 40, 188-194, https://doi.org/10.1021/es051163w, 2006.

Jonsson, A. M., Hallquist, M., and Ljungström, E.: The effect of temperature and water on secondary organic aerosol formation from ozonolysis of limonene, $\Delta^{3}$-carene and $\alpha$-pinene, Atmos. Chem. Phys., 8, 6541-6549, https://doi.org/10.5194/acp-8-65412008, 2008a.

Jonsson, Å. S. A. M., Hallquist, M., Ljungstro, E., Jonsson, Å. S. A. M., and Hallquist, M.: Influence of $\mathrm{OH}$ scavenger on the water effect on secondary organic influence of $\mathrm{OH}$ scavenger on the water effect on secondary organic aerosol formation from ozonolysis of limonene, $\Delta^{3}$-carene, and $\alpha$-pinene, Environ. Sci. Technol., 42, 5938-5944, https://doi.org/10.1021/es702508y, 2008b.

Kanakidou, M., Seinfeld, J. H., Pandis, S. N., Barnes, I., Dentener, F. J., Facchini, M. C., Van Dingenen, R., Ervens, B., Nenes, A., Nielsen, C. J., Swietlicki, E., Putaud, J. P., Balkanski, Y., Fuzzi, S., Horth, J., Moortgat, G. K., Winterhalter, R., Myhre, C. E. L., Tsigaridis, K., Vignati, E., Stephanou, E. G., and Wilson, J.: Organic aerosol and global climate modelling: A review, Atmos. Chem. Phys., 5, 1053-1123, https://doi.org/10.5194/acp-5-10532005, 2005.

Kiendler-Scharr, A., Mensah, A. A., Friese, E., Topping, D., Nemitz, E., Prevot, A. S. H., Äijälä, M., Allan, J., Canonaco, F., Canagaratna, M., Carbone, S., Crippa, M., Dall Osto, M., Day, D. A., De Carlo, P., Di Marco, C. F., Elbern, H., Eriksson, A., Freney, E., Hao, L., Herrmann, H., Hildebrandt, L., Hillamo, R., Jimenez, J. L., Laaksonen, A., McFiggans, G., Mohr, C., O’Dowd, C., Otjes, R., Ovadnevaite, J., Pandis, S. N., Poulain, L., Schlag, P., Sellegri, K., Swietlicki, E., Tiitta, P., Vermeulen, A., Wahner, A., Worsnop, D., and Wu, H. C.: Ubiquity of organic nitrates from nighttime chemistry in the European submicron aerosol, Geophys. Res. Lett., 43, 7735-7744, https://doi.org/10.1002/2016GL069239, 2016

Kourtchev, I., Fuller, S. J., Giorio, C., Healy, R. M., Wilson, E., O'Connor, I., Wenger, J. C., McLeod, M., Aalto, J., Ruuskanen, T. M., Maenhaut, W., Jones, R., Venables, D. S., Sodeau, J. R., Kulmala, M., and Kalberer, M.: Molecular composition of biogenic secondary organic aerosols using ultrahigh-resolution mass spectrometry: Comparing laboratory and field studies, Atmos. Chem. Phys., 14, 2155-2167, https://doi.org/10.5194/acp14-2155-2014, 2014.

Kourtchev, I., Giorio, C., Manninen, A., Wilson, E., Mahon, B., Aalto, J., Kajos, M., Venables, D., Ruuskanen, T., Levula, J., Loponen, M., Connors, S., Harris, N., Zhao, D., KiendlerScharr, A., Mentel, T., Rudich, Y., Hallquist, M., Doussin, J.F., Maenhaut, W., Bäck, J., Petäjä, T., Wenger, J., Kulmala, M., and Kalberer, M.: Enhanced Volatile Organic Compounds emissions and organic aerosol mass increase the oligomer content of atmospheric aerosols, Nat. Sci. Reports, 6, 35038, https://doi.org/10.1038/srep35038, 2016.

Kristensen, K., Watne, A. K., Hammes, J., Lutz, A., Petäjä, T., Hallquist, M., Bilde, M., and Glasius, M.: High-molecular weight dimer esters are major products in aerosols from $\alpha$-pinene ozonolysis and the Boreal forest, Environ. Sci. Tech. Let., 3, 280285, https://doi.org/10.1021/acs.estlett.6b00152, 2016.

Kroll, J. H. and Seinfeld, J. H.: Chemistry of secondary organic aerosol: Formation and evolution of low-volatility organics in the atmosphere, Atmos. Environ., 42, 3593-3624, https://doi.org/10.1016/j.atmosenv.2008.01.003, 2008.
Kroll, J. H., Chan, A. W. H., Ng, N. G. A. L., and Flagan, R. C.: Reactions of semivolatile organics and their Effects on secondary organic aerosol formation, Environ. Sci. Technol., 41, 3545-3550, 2007.

Lee, B. H., Lopez-Hilfiker, F. D., Mohr, C., Kurtén, T., Worsnop, D. R., and Thornton, J. A.: An iodide-adduct high-resolution timeof-flight chemical-ionization mass spectrometer: Application to atmospheric inorganic and organic compounds, Environ. Sci. Technol., 48, 6309-6317, https://doi.org/10.1021/es500362a, 2014a.

Lee, L., Wooldridge, P. J., Gilman, J. B., Warneke, C., de Gouw, J., and Cohen, R. C.: Low temperatures enhance organic nitrate formation: Evidence from observations in the 2012 Uintah Basin Winter Ozone Study, Atmos. Chem. Phys., 14, 12441-12454, https://doi.org/10.5194/acp-14-12441-2014, 2014b.

Lee, B. H., Mohr, C., Lopez-Hilfiker, F. D., Lutz, A., Hallquist, M., Lee, L., Romer, P., Cohen, R. C., Iyer, S., Kurten, T., Hu, W., Day, D. A., Campuzano-Jost, P., Jimenez, J. L., Xu, L., Ng, N. L., Guo, H., Weber, R. J., Wild, R. J., Brown, S. S., Koss, A., de Gouw, J., Olson, K., Goldstein, A. H., Seco, R., Kim, S., McAvey, K., Shepson, P. B., Starn, T., Baumann, K., Edgerton, E. S., Liu, J., Shilling, J. E., Miller, D. O., Brune, W., Schobesberger, S., D'Ambro, E. L., and Thornton, J. A.: Highly functionalized organic nitrates in the southeast United States: Contribution to secondary organic aerosol and reactive nitrogen budgets, P. Natl. Acad. Sci. USA, 113, 1516-1521, https://doi.org/10.1073/pnas.1508108113, 2016.

Leungsakul, S., Jaoui, M., and Kamens, R. M.: Kinetic mechanism for predicting secondary organic aerosol formation from the reaction of d-limonene with ozone, Environ. Sci. Technol., 39, 9583-9594, https://doi.org/10.1021/es0492687, 2005.

Lopez-Hilfiker, F. D., Mohr, C., Ehn, M., Rubach, F., Kleist, E., Wildt, J., Mentel, T. F., Lutz, A., Hallquist, M., Worsnop, D., and Thornton, J. A.: A novel method for online analysis of gas and particle composition: Description and evaluation of a Filter Inlet for Gases and AEROsols (FIGAERO), Atmos. Meas. Tech., 7, 983-1001, https://doi.org/10.5194/amt-7-983-2014, 2014.

Lopez-Hilfiker, F. D., Mohr, C., Ehn, M., Rubach, F., Kleist, E., Wildt, J., Mentel, Th. F., Carrasquillo, A. J., Daumit, K. E., Hunter, J. F., Kroll, J. H., Worsnop, D. R., and Thornton, J. A.: Phase partitioning and volatility of secondary organic aerosol components formed from $\alpha$-pinene ozonolysis and $\mathrm{OH}$ oxidation: the importance of accretion products and other low volatility compounds, Atmos. Chem. Phys., 15, 7765-7776, https://doi.org/10.5194/acp-15-7765-2015, 2015.

McKinney, W.: Data structures for statistical computing in Python, Proc. 9th Python Sci. Conf., 1697900 (Scipy), 51-56, 2010.

McKinney, W.: pandas: A foundational Python library for data analysis and statistics, Python High Perform, Sci. Comput., 1, 1-9, 2011.

Mentel, T. F., Springer, M., Ehn, M., Kleist, E., Pullinen, I., Kurtén, T., Rissanen, M., Wahner, A., and Wildt, J.: Formation of highly oxidized multifunctional compounds: Autoxidation of peroxy radicals formed in the ozonolysis of alkenes - deduced from structure-product relationships, Atmos. Chem. Phys., 15, 67456765, https://doi.org/10.5194/acp-15-6745-2015, 2015.

Müller, L., Reinnig, M.-C., Warnke, J., and Hoffmann, Th.: Unambiguous identification of esters as oligomers in secondary organic aerosol formed from cyclohexene and cyclohexene $/ \alpha$ - 
pinene ozonolysis, Atmos. Chem. Phys., 8, 1423-1433, https://doi.org/10.5194/acp-8-1423-2008, 2008.

Murphy, B. N., Donahue, N. M., Robinson, A. L., and Pandis, S. N.: A naming convention for atmospheric organic aerosol, Atmos. Chem. Phys., 14, 5825-5839, https://doi.org/10.5194/acp14-5825-2014, 2014.

Myhre, G., Shindell, D., Bréon, F.-M., Collins, W., Fuglestvedt, J., Huang, J., Koch, D., Lamarque, J.-F., Lee, D., Mendoza, B., Nakajima, T., Robock, A., Stephens, G., Takemura, T., and Zhan, H.: Anthropogenic and natural radiative forcing: In Climate Change 2013: The Physical Science Basis. Contribution of Working Group I to the Fifth Assessment Report of the Intergovernmental Panel on Climate Change, Cambridge Univ. Press, Cambridge, United Kingdom New York, NY, USA, 659-740, https://doi.org/10.1017/CBO9781107415324.018, 2013.

Nah, T., McVay, R. C., Zhang, X., Boyd, C. M., Seinfeld, J. H., and $\mathrm{Ng}, \mathrm{N}$. L.: Influence of seed aerosol surface area and oxidation rate on vapor wall deposition and SOA mass yields: a case study with $\alpha$-pinene ozonolysis, Atmos. Chem. Phys., 16, 9361-9379, https://doi.org/10.5194/acp-16-9361-2016, 2016.

Ng, N. L., Brown, S. S., Archibald, A. T., Atlas, E., Cohen, R. C., Crowley, J. N., Day, D. A., Donahue, N. M., Fry, J. L., Fuchs, H., Griffin, R. J., Guzman, M. I., Herrmann, H., Hodzic, A., Iinuma, Y., Jimenez, J. L., Kiendler-Scharr, A., Lee, B. H., Luecken, D. J., Mao, J., McLaren, R., Mutzel, A., Osthoff, H. D., Ouyang, B., Picquet-Varrault, B., Platt, U., Pye, H. O. T., Rudich, Y., Schwantes, R. H., Shiraiwa, M., Stutz, J., Thornton, J. A., Tilgner, A., Williams, B. J., and Zaveri, R. A.: Nitrate radicals and biogenic volatile organic compounds: oxidation, mechanisms, and organic aerosol, Atmos. Chem. Phys., 17, 2103-2162, https://doi.org/10.5194/acp-17-2103-2017, 2017.

Pathak, R. K., Salo, K., Emanuelsson, E. U., Cai, C., Lutz, A., Hallquist, A. M., and Hallquist, M.: Influence of ozone and radical chemistry on limonene organic aerosol production and thermal characteristics, Environ. Sci. Technol., 46, 11660-11669, 2012.

Paulot, F., Crounse, J. D., Kjaergaard, H. G., Kroll, J. H., Seinfeld, J. H., and Wennberg, P. O.: Isoprene photooxidation: New insights into the production of acids and organic nitrates, Atmos. Chem. Phys., 9, 1479-1501, https://doi.org/10.5194/acp-9-14792009, 2009.

Pedregosa, F., Grisel, O., Weiss, R., Passos, A., and Brucher, M.: Scikit-learn: Machine learning in Python, J. Mach. Learn. Res., 12, 2825-2830, 2011.

Perraud, V., Bruns, E. A, Ezell, M. J., Johnson, S. N., Greaves, J., and Finlayson-Pitts, B. J.: Identification of organic nitrates in the $\mathrm{NO}_{3}$ radical initiated oxidation of alpha-pinene by atmospheric pressure chemical ionization mass spectrometry, Environ. Sci. Technol., 44, 5887-93, https://doi.org/10.1021/es1005658, 2010.

Perring, A. E., Bertram, T. H., Wooldridge, P. J., Fried, A., Heikes, B. G., Dibb, J., Crounse, J. D., Wennberg, P. O., Blake, N. J., Blake, D. R., Brune, W. H., Singh, H. B., and Cohen, R. C.: Airborne observations of total RONO2: New constraints on the yield and lifetime of isoprene nitrates, Atmos. Chem. Phys., 9, 14511463, https://doi.org/10.5194/acp-9-1451-2009, 2009.

Perring, A. E., Pusede, S. E., and Cohen, R. C.: An observational perspective on the atmospheric impacts of alkyl and multifunctional nitrates on ozone and secondary organic aerosol, Chem. Rev., 113, 5848-5870, 2013.
Presto, A. A., Hartz, K. E. H., and Donahue, N. M.: Secondary organic aerosol production from terpene ozonolysis, 1. Effect of UV radiation, Environ. Sci. Technol., 39, 7036-7045, https://doi.org/10.1021/es050174m, 2005a.

Presto, A. A., Hartz, K. E. H., Donahue, N. M., Huff Hartz, K. E., Donahue, N. M., Hartz, K. E. H., Donahue, N. M., Huff Hartz, K. E., and Donahue, N. M.: Secondary organic aerosol production from terpene ozonolysis, 2. Effect of NOx concentration, Environ. Sci. Technol., 39, 7046-7054, https://doi.org/10.1021/es050400s, 2005b.

Raschka, S.: Python machine learning, edited by A. Hussain, Packt Publishin Ltd., Birmingham, UK, ISBN-10: 1783555130, available from: www.packtpub.com, 2015.

Rindelaub, J. D., McAvey, K. M., and Shepson, P. B.: Determination of $\alpha$-pinene-derived organic nitrate yields: particle phase partitioning and hydrolysis, Atmos. Chem. Phys. Discuss., 14, 33013335, https://doi.org/10.5194/acpd-14-3301-2014, 2014.

Rindelaub, J. D., Mcavey, K. M., and Shepson, P. B.: The photochemical production of organic nitrates from $\alpha$-pinene and loss via acid-dependent particle phase hydrolysis, Atmos. Environ., 100, 193-201, https://doi.org/10.1016/j.atmosenv.2014.11.010, 2015.

Rindelaub, J. D., Borca, C. H., Hostetler, M. A., Slade, J. H., Lipton, M. A., Slipchenko, L. V., and Shepson, P. B.: The acid-catalyzed hydrolysis of an $\alpha$-pinene-derived organic nitrate: kinetics, products, reaction mechanisms, and atmospheric impact, Atmos. Chem. Phys., 16, 15425-15432, https://doi.org/10.5194/acp-1615425-2016, 2016.

Roberts, J. M.: Chemistry of organic nitrates, Atmos. Environ., 24, 243-287, 1990.

Rollins, A. W., Browne, E. C., Pusede, S. E., Wooldridge, P. J., Gentner, D. R., Goldstein, A. H., Liu, S., Day, D. A., and Cohen, R. C.: Evidence for $\mathrm{NO}_{x}$ control over nighttime SOA formation, Science, 267, 1210-1212, 2012.

Rollins, A. W., Pusede, S., Wooldridge, P., Min, K.-E., Gentner, D. R., Goldstein, A. H., Liu, S., Day, D. A., Russell, L. M., Rubitschun, C. L., Surratt, J. D., and Cohen, R. C.: Gas/particle partitioning of total alkyl nitrates observed with TDLIF in Bakersfield, J. Geophys. Res.-Atmos., 118, 6651-6662, https://doi.org/10.1002/jgrd.50522, 2013.

Rousseeuw, P. J.: Silhouettes: A graphical aid to the interpretation and validation of cluster analysis, J. Comput. Appl. Math., 20, 53-65, https://doi.org/10.1016/0377-0427(87)90125-7, 1987.

Saunders, S. M., Jenkin, M. E., Derwent, R. G., and Pilling, M. J.: Protocol for the development of the Master Chemical Mechanism, MCM v3 (Part A): Tropospheric degradation of nonaromatic volatile organic compounds, Atmos. Chem. Phys., 3, 161-180, https://doi.org/10.5194/acp-3-161-2003, 2003.

Singh, H. B. and Hanst, P. L.: Peroxyacetyl nitrate (PAN) in the unpolluted atmosphere: An important reservoir for nitrogen oxides, Geopys. Res. Lett., 8, 941-944, 1981.

Smith, J. N., Dunn, M. J., VanReken, T. M., Iida, K., Stolzenburg, M. R., McMurry, P. H., and Huey, L. G.: Chemical composition of atmospheric nanoparticles formed from nucleation in Tecamac, Mexico: Evidence for an important role for organic species in nanoparticle growth, Geophys. Res. Lett., 35, 2-6, https://doi.org/10.1029/2007GL032523, 2008.

Spittler, M., Barnes, I., Bejan, I., Brockmann, K. J. J., Benter, T., and Wirtz, K.: Reactions of $\mathrm{NO}_{3}$ radicals with limonene and $\alpha$ - 
pinene: Product and SOA formation, Atmos. Environ., 40, 116127, https://doi.org/10.1016/j.atmosenv.2005.09.093, 2006.

Stark, H., Yatavelli, R. L. N., Thompson, S. L., Kang, H., Krechmer, J. E., Kimmel, J. R., Palm, B. B., Hum, W., Hayes, P. L., Day, D. A., Campuzano-Jost, P., Canagaratna, M. R., Jayne, J. T., Worsnop, D. R., and Jiminez, J. L.: Impact of thermal decomposition on thermal desorption instruments: Advantage of hermogram analyis for quantifying volatility distributions of organic species, Environ. Sci. Technol., 51, 85491-8500, 2017.

Sun, T., Wang, Y., Zhang, C., Sun, X., and Wang, W.: The chemical mechanism of the limonene ozonolysis reaction in the SOA formation: A quantum chemistry and direct dynamic study, Atmos. Environ., 45, 1725-1731, https://doi.org/10.1016/j.atmosenv.2010.12.054, 2011.

Swedish National Data Service (SND): Characterization of organic nitrate constituents of secondary organic aerosol (SOA) from nitrate-radical-initiated oxidation of limonene using highresolution chemical, https://doi.org/10.5878/002983, 2018.

Temple, P. J. and Taylor, O. C.: World-wide ambient measurements of peroxyacetyl nitrate (PAN) and implications for plant injury, Atmos. Environ., 17, 1583-1587, https://doi.org/10.1016/00046981(83)90311-6, 1983

Tolocka, M. P., Jang, M., Ginter, J. M., Cox, F. J., Kamens, R. M., and Johnston, M. V.: Formation of oligomers in secondary organic aerosol, Environ. Sci. Technol., 38, 1428-1434, https://doi.org/10.1021/es035030r, 2004.

Van Der Walt, S., Colbert, S. C., and Varoquaux, G.: The NumPy array: A structure for efficient numerical computation, Comput. Sci. Eng., 13, 22-30, https://doi.org/10.1109/MCSE.2011.37, 2011.

Wainman, T., Zhang, J., Weschler, C. J., and Lioy, P. J.: Ozone and limonene in indoor air: A source of submicron particle exposure, Environ. Health Perspect., 108, 1139-1145, https://doi.org/10.1289/ehp.001081139, 2000.
Wehner, B., Petäjä, T., Boy, M., Engler, C., Birmili, W., Tuch, T., Wiedensohler, A., and Kulmala, M.: The contribution of sulfuric acid and non-volatile compounds on the growth of freshly formed particles at Melpitz, Geophys. Res. Lett., 32, L17810, https://doi.org/10.1063/1.4803246, 2005.

Xu, L., Williams, L. R., Young, D. E., Allan, J. D., Coe, H., Massoli, P., Fortner, E., Chhabra, P., Herndon, S., Brooks, W. A., Jayne, J. T., Worsnop, D. R., Aiken, A. C., Liu, S., Gorkowski, K., Dubey, M. K., Fleming, Z. L., Visser, S., Prévôt, A. S. H., and Ng, N. L.: Wintertime aerosol chemical composition, volatility, and spatial variability in the greater London area, Atmos. Chem. Phys., 16, 1139-1160, https://doi.org/10.5194/acp-16-1139-2016, 2016.

Yatavelli, R. L. N., Lopez-Hilfiker, F., Wargo, J. D., Kimmel, J. R., Cubison, M. J., Bertram, T. H., Jimenez, J. L., Gonin, M., Worsnop, D. R., and Thornton, J. A.: A Chemical Ionization High-Resolution Time-of-Flight Mass Spectrometer Coupled to a Micro Orifice Volatilization Impactor (MOVI-HRToF-CIMS) for analysis of gas and particlephase organic species, Aerosol Sci. Technol., 46, 1313-1327, https://doi.org/10.1080/02786826.2012.712236, 2012.

Youssefi, S. and Waring, M. S.: Transient secondary organic aerosol formation from d-limonene and a-pinene ozonolysis in indoor environments, Indoor Air 2014 - 13th Int. Conf. Indoor Air Qual. Clim., 145-152, 2014.

Zhang, J., Hartz, K. E. H., Pathak, R. K., Pandis, S. N., and Donahue, N. M.: Secondary organic aerosol formation from limonene ozonolysis: $\mathrm{NO}_{x}$ and ultraviolet effects, J. Phys. Chem. A, 110, 11053-11063, 2006.

Ziemann, P. J. and Atkinson, R.: Kinetics, products, and mechanisms of secondary organic aerosol formation, Chem. Soc. Rev., 41, 6582, https://doi.org/10.1039/c2cs35122f, 2012. 